\title{
Perioperative management of patients with pre-excitation syndromes
}

\author{
Chryssoula Staikou ${ }^{1}$, Mattheos Stamelos ${ }^{1}$, Eftyhios Stavroulakis ${ }^{2}$
}

${ }^{1}$ Department of Anaesthesiology, Aretaieio Hospital, Medical School, University of Athens, Athens, Greece
${ }^{2}$ Department of Anaesthesiology, 401 Military Hospital, Athens, Greece

\begin{abstract}
Patients with pre-excitation abnormalities are at a high risk for life-threatening perioperative arrhythmias. In Wolff-Parkinson-White syndrome, the anaesthetics used for invasive diagnostic testing/ablation, should not affect cardiac electrophysiology; propofol, sevoflurane, fentanyl, sufentanil, alfentanil are suitable. In non-ablative surgery, propofol, sevoflurane, isoflurane, fentanyl, alfentanil, sufentanil have been used safely. Among neuromuscular blockers, cis-atracurium, rocuronium and vecuronium are good choices. Ketamine, pancuronium and pethidine should be avoided because of their sympathomimetic actions. Anticholinergic/ anticholinesterase combinations for neuromuscular block reversal should preferably be omitted, while sugammadex seems more attractive. In regional anaesthesia, addition of epinephrine and high sympathetic blocks should be avoided. Hypotension should be treated with pure alpha-adrenergic agonists. Other preexcitation abnormalities associated with different accessory pathways are the Mahaim Fiber and LownGanong-Levine syndrome. Sympathetic activation should be avoided. Total intravenous anaesthesia with propofol probably represents the safest option. A careful anaesthetic plan and close cooperation with cardiologists are mandatory for successful management.
\end{abstract}

Keywords: Pre-excitation; Wolff-Parkinson-White syndrome; Mahaim fiber syndrome; Lown-GanongLevine syndrome; anaesthesia

\section{Introduction}

In 1893, the physiologist S. Kent reported the existence of atrio-ventricular (AV) pathways in mammalian hearts [1], while in 1930, the cardiologists Wolff, Parkinson and White described an "unusual cardiac mechanism" manifested as paroxysmal tachycardia or atrial fibrillation (AF) and characterised by a

Address for correspondence:

Chryssoula Staikou MD, PhD, DESA Department of Anaesthesiology Aretaieio Hospital, Medical School University of Athens 76 Vassilissis. Sophias Ave. 11528, Athens, Greece E-mail: c_staikou@yahoo.gr bundle-branch block and a short PR interval on the electrocardiogram (ECG) [2]. Since then, this electrophysiological abnormality has attracted the interest of investigators [3,4], while the term "pre-excitation" was first used by Öhnell in 1944 [5].

Normally, the cardiac electrical impulses are generated in the sino-atrial (SA) node and then are spread to the right and left atrium. After passing through the $\mathrm{AV}$ node and His bundle, the stimuli reach the Purkinje fibers and propagate across the ventricular myocardium. The action potential of the AV node depends on slow inward calcium current which delays AV conduction as the heart rate (HR) increases, thus preventing fast supraventricular rhythms to reach the ventricles. However, abnormal AV muscular connections may serve as accessory pathways (APs) allowing atrial impulses to bypass the critical delay in the AV node. In most APs, the action potential relies on rapid inward 
sodium currents. As a result, the stimuli travel towards the ventricles faster than usual, causing early depolarisation of the ventricular myocardium, a condition named "pre-excitation" [5]. The quick transmission of cardiac impulses combined with fast HRs may predispose to detrimental ventricular tachycardias (VTs), even ventricular fibrillation(VF) [6-8].

More than one APs may exist in the same patient, located almost anywhere in the AV groove [5]. The AP conduction is usually bidirectional, but rarely it may be only retrograde (ventriculo-atrial). In this case, the pathways are called "concealed" due to the absence of electrocardiographic signs of pre-excitation $[3,5]$.

In the past, the term "pre-excitation" was exclusively used for the Wolff-Parkinson-White (WPW) syndrome. Today, other pre-excitation mechanisms due to different APs have also been identified. Specifically, Mahaim Fiber and Lown-Ganong-Levine syndrome represent pre-excitation conditions which are encountered more rarely than the well known WPW.

Perioperative management of patients with preexcitation may become quite challenging, especially if there is no time for adequate preoperative investigation and clinical optimisation - as in emergencies -, or even worse, in undiagnosed cases. It is possible that the poorly controlled or unknown underlying electrophysiological abnormality will become unmasked during anaesthesia and surgery, giving rise to potentially lifethreatening arrhythmias.

In the literature, pre-excitation syndromes have been mainly approached from the view of the disease (i.e. presentation, diagnosis, treatment), while anaesthetic data are scarce. The present review aims to focus on the perioperative management of patients with WPW and two other, less known pre-excitation syndromes.

We conducted a Pubmed ${ }^{\circledR}$ literature search for all types of published articles (up to February 2018) using the terms: "Preexcitation", "Pre-excitation", "WolffParkinson-White syndrome", "WPW syndrome" "Mahaim pre-excitation", "Mahaim fibers", "LownGanong-Levine syndrome" and "anaesthesia" or "perioperative management" or "perioperative care" in all possible combinations. Articles in languages other than English were used, if they had a detailed English abstract containing specific and relevant information. We identified 75 suitable articles. Additionally, seven publications were found by manual searching. Since the number of randomised controlled trials (RCTs) was small, the articles we considered were mostly observational studies, retrospective studies, case series and case reports. We also used articles providing information on genetics, clinical presentation, diagnostic and therapeutic approach of the disorders. In total 119 articles were included in the present review.

\section{The WPW syndrome}

\section{Pathophysiology and clinical features of WPW syndrome}

The main pathophysiological characteristic of the syndrome is the existence of an accessory AV pathway, named "bundle of Kent". It represents an abnormal fibro-muscular connection which ends up directly into the ventricular myocardium and has remained after incomplete AV separation $[9,10]$. It may connect the left atrium and ventricle (type A), or the right atrium and ventricle (type B), and can conduct the stimuli bidirectionally $[5,10]$. The prevalence of WPW syndrome is $0.1-3.1 \%$ in general population, higher in men [10]. Most cases are sporadic, while the more rare familial form is characterised by autosomal dominant inheritance and has been linked to chromosome 7q34q36 and mutations in the gamma-2 regulatory subunit of AMP-activated protein kinase gene (PRKAG2) [11].

The ECG pattern consists of a short PQ interval $(<$ $120 \mathrm{~ms}$ ), a slurred upstroke at the beginning of QRS (delta wave) and a broad QRS complex (> $120 \mathrm{~ms}$ ). This characteristic "WPW pattern" represents an exclusively ECG feature, found 10-100 times more frequently than the actual "WPW syndrome" which refers to the combination of the ECG pattern with symptomatology $[9,12]$. While many individuals with a WPW-pattern will remain asymptomatic for life, patients with WPW-syndrome usually develop arrhythmias between the ages $20-40$ years [10]. The commonest symptom is palpitations, while dizziness, lightheadedness, chest pain, shortness of breath and syncopal episodes may also occur. Rarely, the first manifestation of the disorder is cardiac arrest [10].

The most common arrhythmias are atrioventricular reentrant tachycardias (AVRTs) [10], usually orthodromic. In orthodromic tachycardias, the stimuli travel down the AV node and return back via the AP, producing narrow QRS complexes on the ECG [9]. Less often, the conduction proceeds down the AP and retrogradely up the AV node, causing antidromic tachycardias with a wide QRS [9]. Finally, AF or atrial flutter may develop; both rhythms can be dangerous if rapid anterograde conduction occurs through an AP with a short refractory period. In this case, many atrial impulses may travel towards ventricles, causing extremely fast ventricular responses, VF and sudden cardiac death [12]. Risk factors for life-threatening arrhythmias are APs with short anterograde effective refractory period, short RR interval in pre-excited AF, inducible AVRT during electrophysiology studies (EPS), multiple APs, male gender and young age $[13,14]$. Sometimes, pre-excitation may imitate acute myocar- 
dial infarction, while negative delta waves can also be confused with pathological Q waves $[15,16]$. Further investigation for definite diagnosis includes cardiac troponin I levels or echocardiographic assessment of myocardial wall movement $[15,16]$.

The initial diagnosis of WPW syndrome is based on the ECG pattern combined with symptomatology. More specific examination includes Holter monitoring and exercise or pharmacological testing with ajmaline or procainamide [12]. Finally, EPS may be required to elucidate the abnormality and identify the exact AP location and its characteristics.

Treatment, conservative or invasive, is case-specific, since both long-term antiarrhythmic therapy and AP catheter ablation are not without risks, namely drugside effects, or heart injury, ischaemia and thromboembolism due to catheterisation [10]. The decision depends on the risk/benefit ratio, according to the type, severity and frequency of symptoms [10].

\section{Anaesthetic considerations in WPW syndrome}

Patients with WPW syndrome may require anaesthesia for EPS/ablation or for non-ablative procedures. In diagnostic/therapeutic interventions, anaesthetics should not interfere with cardiac electrophysiology, while in non-ablative surgery, drugs should ideally prevent - or at least not facilitate - the generation of arrhythmias associated with APs.

Anaesthesia and surgery may unmask an undiagnosed syndrome, and suspicious cases should be referred for further investigation before elective surgery. A detailed cardiac history during pre-anaesthetic evaluation is the corner stone of not missing undiagnosed patients [12]. Apart from a 12-lead ECG, Holter monitoring may be useful, especially in intermittent WPW. Echocardiography can reveal congenital cardiac abnormalities that coexist in $7-20 \%$ of patients, such as Ebstein's anomaly, valve lesions, cardiac hypertrophy, atrial aneurysms and septal defects $[10,11,17]$. An EPS may also be needed; the benefit of postponing an elective surgery for EPS testing should be examined. The capability of rapid anterograde AP conduction increases the risk of sudden death and is an indication for radiofrequency catheter ablation (RFCA) to precede surgery [17]. Diagnosed patients should be carefully assessed preoperatively regarding their symptoms and current treatment, and should be clinically optimised. Cardiological consultation and close cooperation are mandatory for a safe management plan.

\section{Anaesthesia for electrophysiologic investigation and ablation}

Although cardiac complications during EPS are usually not related to the anaesthetic technique [18, 19], accurate diagnostic mapping and successful ablation may be impaired by anaesthetic drugs that alter the conduction in the normal and accessory pathways [20]. Thus, agents with minimal effects on cardiac electrophysiology should be preferred [19].

Among general anaesthetics, propofol is considered appropriate for use in EPS/ablations, as it does not impede the generation of diagnostic supraventricular tachycardias (SVTs) [20]. Despite reports about bradycardia, AV block, even asystole [21], Sharpe and colleagues suggest that propofol per se has no direct effects on SA or AV node or intra-atrial conduction [22]. Moreover, propofol did not affect the refractory periods of normal and accessory pathways and did not interfere with EPS/ablation in a study with adult WPW patients [22]. Also, in children, propofol-based anaesthesia did not cause problems during EPS/RFCA $[23,24]$. Two randomised studies in youngsters undergoing RFCA, showed that propofol was similarly suitable with isoflurane, both leaving unaffected the SA and AV node function $[25,26]$. Nevertheless, the findings about isoflurane are not consistent; experimental research has shown that it may depress the SA node discharge, and prolong the $\mathrm{AV}$ and ventricular conduction [21]. Similarly, in adults undergoing surgical cryoablation, isoflurane at $1 \mathrm{MAC}$ was associated with slower conduction in normal and aberrant systems [27]. Also, a retrospective study of children showed that isoflurane prolongs the atrial, ventricular and AP anterograde effective refractory period [28]. Notably, not only isoflurane [29], but also enflurane [29, 30], and halothane [29] are considered rather unsuitable agents for EPS/ablations, since they prolong the refractory period and slow the conduction in normal and accessory pathways, thus interfering with interpretation of tests and determination of ablation success. In patients receiving halothane anaesthesia, persistent delta waves and difficulty with AP localisation have also been reported [31]. Conversely, experimental studies have shown that sevoflurane exerts only moderate effects on cardiac electrophysiology [21]. Additionally, clinical data suggest that sevoflurane has a favorable profile for use in EPS/ablations [32, 33]. In adults, it did not affect the function of SA node or AV and AP conduction, and did not prevent diagnostic reciprocating tachycardias [32]. Also in children, when given after propofol, sevoflurane caused only moderate prolongation of the AP antegrade effective refractory period, without interfering with the ablative procedure [33]. On the other hand, desflurane at 1 MAC prolonged the AP effective refractory period and impaired the induction of diagnostic SVTs in paediatric patients [24]. The authors considered it unsuitable for EPS/ablative procedures [24].

Regarding opioids, animal studies have shown that morphine may exert a direct negative action on SA 
and AV nodes, while fentanyl may decrease the SR, but this action is not clinically significant [21]. In WPW patients, fentanyl was found to exert no effect on AP refractory period or SA conduction [34,35], but it may increase the cardiac vagal tone causing prolongation of the sinus node recovery time, especially when combined with propofol [35]. More pronounced effects have been reported for remifentanil: both experimental and clinical studies have shown that it may depress sinus node automaticity and delay SA and AV conduction [21, 36-38]. These properties render remifentanil less attractive for use in EPS, as it may interfere with testing and results. On the contrary, sufentanil is devoid of significant direct actions on the normal intracardiac or AP conduction [21, 29]. Also, an alfentanil/ midazolam-based anaesthesia has been suggested as suitable, because it leaves unaffected both the AV node and aberrant bundle [39].

Among adjuvants, dexmedetomidine has been studied in EPS/ablative procedures. A prospective trial in children receiving thiopental/ketamine anaesthesia showed that i.v. dexmedetomidine $(1 \mu \mathrm{g} / \mathrm{kg}$ followed by $0.7 \mu \mathrm{g} / \mathrm{kg} / \mathrm{h}$ infusion), given after successful ablation caused significant sinus and AV node depression, without affecting the atrial or ventricular refractoriness [40]. The authors consider that the drug may interfere with the generation of tachycardias and interpretation of measurements [40]. Different findings were reported by a retrospective study of children receiving propofol or sevoflurane: dexmedetomidine $(0.5-1 \mu \mathrm{g} / \mathrm{kg}$ followed by $0.5-1 \mu \mathrm{g} / \mathrm{kg} / \mathrm{h}$ infusion) given during EPS/ ablation was associated with increased need for isoproterenol for SVT induction, but did not affect the electrophysiological parameters or the interventions and their success [41]. Regarding other factors, controlled ventilation in patients subjected to RFCA under GA was found to facilitate the procedure and increase the ablation success [42].

The published clinical trials on the use of anaesthetics for EPS/ablation are presented in Table 1.

\section{Anaesthesia for non-ablative surgical procedures}

In patients with WPW syndrome undergoing nonablative surgery, antiarrhythmic treatment should be continued perioperatively. Additionally, sympathetic stimulation should be avoided, because it may shorten the AP refractory period and facilitate life-threatening arrhythmias [43-47]. Anaesthetics and adjuvants that increase AP refractoriness should be preferred.

Regarding volatiles, early research demonstrated that enflurane was advantageous over both halothane and isoflurane, because it increased the AP refractoriness more than the other two agents, while it was the only volatile that did not prolong the coupling interval, thus the vulnerable time for SVT generation
[29]. Also, in two older case reports enflurane was described as a safe agent for WPW patients [48, 49]. Conversely, Dobkowski and colleagues suggested that enflurane may trigger arrhythmias and should not be used in WPW syndrome [30]. In a more recent report, isoflurane was preferred among other volatiles due to its property to prolong the AP refractory period and decrease the likelihood of tachycardias [50]. Similarly, most investigators consider isoflurane as a safe choice for patients with WPW [45, 51-53]. Although halothane could be preferred for its bronchodilatory properties in selected cases [52], its potential to sensitize myocardium to catecholamines is a major drawback. Sevoflurane seems less advantageous than isoflurane, since it does not prolong the AP refractory period [32]. Nevertheless, it has been used safely for the maintenance of anaesthesia in a number of cases [54-57]. Also, no adverse effects have been reported for nitrous oxide [34, 48$49,54,58]$. Finally, desflurane has been found to prolong the refractory period of AP, without affecting the electrophysiology of sinoartrial node and normal pathways [24], but the available data are limited [59].

Among intravenous anaesthetics, propofol does not affect the AP refractory period [22]. Induction or maintenance of anaesthesia with propofol combined with fentanyl has been associated with cardiovascular stability in WPW patients [44, 50, 54, 55, 58-63]. Moreover, it was reported that delta waves disappeared after propofol administration and reappeared after its discontinuation [58]. Similarly, a decrease of QRS duration and return of PR interval into normal ranges were observed when propofol infusion $(25 \mu \mathrm{g} /$ $\mathrm{kg} / \mathrm{min}$ ) was added to isoflurane anaesthesia [63]. Thiopental has been used in several cases, and small (50 $\mathrm{mg}$ ) to moderate doses $(4 \mathrm{mg} / \mathrm{kg})$ did not cause conduction problems [18, 45, 48, 51, 53, 64, 65]. Nevertheless, in the early 70's its safety had been questioned due to observed ECG changes after anaesthesia induction; the ECG signs of acute myocardial infarction were attributed to enhanced conduction in the AP caused by thiopental [66-68]. Experimental data suggest that etomidate in high plasma concentrations may decrease the SR and prolong AV conduction [21]. Nevertheless, in common clinical doses it offers significant cardiovascular stability, quite desirable in patients with WPW, although specific data are rather limited [49]. Ketamine should better be avoided due to its sympathomimetic effects.

Most opioids are suitable for patients at risk for tachyarrhythmias, since they maintain haemodynamic stability with a mild reduction of HR [21]. Additionally, alfentanil/midazolam anaesthesia produces no significant effects on AP conduction and the refractory period [39], while the sufentanil/lorazepam combination may even cause a mild prolongation of the AP effective 
Table 1. Clinical studies on the anaesthetic management of patients with Wolff Parkinson White syndrome undergoing electrophysiological studies and/or ablation of accessory pathways

\begin{tabular}{|c|c|c|c|}
\hline Author / study & Patients & Type of anaesthesia / Drugs used & Findings / Suggestions \\
\hline $\begin{array}{l}\text { Irish }(1988)^{18} \text {, } \\
\text { retrospective }\end{array}$ & $\begin{array}{l}\text { Children, adolescents, } \\
\text { adults with AV APs } \\
\mathrm{n}=181 \text { (197 procedures) }\end{array}$ & $\begin{array}{l}\text { GA with various drugs: diazepam, fentanyl, } \\
\text { scopolamine, droperidol, thiopental, halothane, } \\
\text { enflurane, isoflurane, } \mathrm{N}_{2} \mathrm{O} \text {, pancuronium, } \\
\text { succinylcholine, tubocurarine }\end{array}$ & $\begin{array}{l}\text {-Incidence of arrhythmias not related to } \\
\text { anaesthetic agent } \\
\text {-Standard anaesthetic methods and drugs can } \\
\text { be used in most cases }\end{array}$ \\
\hline $\begin{array}{l}\text { Joung }(2006)^{19} \text {, } \\
\text { retrospective }\end{array}$ & $\begin{array}{l}\text { Children, adolescents } \\
\mathrm{n}=131 \text { (47 WPW) }\end{array}$ & $\begin{array}{l}\text { Various anaesthetic techniques: } \\
\text { No sedation, conscious sedation, deep sedation, } \\
\text { GA (midazolam, fentanyl, ketamine, propofol) }\end{array}$ & $\begin{array}{l}\text {-Complication incidence did not differ and } \\
\text { was not related to anaesthetic method }\end{array}$ \\
\hline $\begin{array}{l}\text { Moore }(2011)^{20} \\
\text { retrospective }\end{array}$ & $\begin{array}{l}\text { Children, adolescents } \\
\mathrm{n}=151\end{array}$ & GA: propofol infusion & $\begin{array}{l}\text { - GA may interfere with risk stratification / } \\
\text { Propofol is a good choice }\end{array}$ \\
\hline $\begin{array}{l}\text { Sharpe }(1995)^{22} \text {, } \\
\text { prospective }\end{array}$ & Adults, $\mathrm{n}=12$ & $\begin{array}{l}\text { GA: alfentanil, midazolam, vecuronium } / \pm \\
\text { propofol for maintenance }\end{array}$ & $\begin{array}{l}\text { - Propofol: no effect on AV and AP } \\
\text { conduction / suitable for EPS / ablation }\end{array}$ \\
\hline $\begin{array}{l}\text { Pappone }(2004)^{23}, \\
\text { RCT }\end{array}$ & $\begin{array}{l}\text { Children, } \mathrm{n}=47(20 \\
\text { received intervention) }\end{array}$ & GA: propofol & •Propofol: no significant complications \\
\hline $\begin{array}{l}\text { Hino }(2017)^{24} \\
\text { randomized } \\
\text { crossover study }\end{array}$ & Children, $n=36$ & GA with propofol or desflurane at 0.5 or $1 \mathrm{MAC}$ & $\begin{array}{l}\text { - Desflurane } 1 \mathrm{MAC}: \uparrow \text { AP refractory period, } \\
\text { no effect on normal pathways, impaired SVT } \\
\text { induction. } \\
\text {-Desflurane: unsuitable for EPS/ablation } \\
\text {-Propofol: suitable for EPS/ablation }\end{array}$ \\
\hline $\begin{array}{l}\text { Lavoie (1995)25, } \\
\text { RCT }\end{array}$ & $\begin{array}{l}\text { Children, adolescents } \\
\mathrm{n}=20(9 \mathrm{WPW})\end{array}$ & $\begin{array}{l}\text { GA: alfentanil, thiopental, pancuronium, } \mathrm{N}_{2} \mathrm{O} \text {, } \\
\text { propofol or isoflurane }\end{array}$ & $\begin{array}{l}\text {-Neither propofol nor isoflurane had } \\
\text { significant effects on SA or AV node }\end{array}$ \\
\hline $\operatorname{Erb}(2002)^{26}, \mathrm{RCT}$ & $\begin{array}{l}\text { Children, adolescents } \\
\mathrm{n}=60\end{array}$ & $\begin{array}{l}\text { GA: midazolam, sevoflurane, pancuronium, } \\
\text { fentanyl, } \mathrm{N}_{2} \mathrm{O} \text {, isoflurane or propofol }\end{array}$ & $\begin{array}{l}\text {-SVT induction independent of propofol or } \\
\text { isoflurane administration } \\
\text {-Isoflurane and propofol equally suitable }\end{array}$ \\
\hline $\begin{array}{l}\text { Dobkowski } \\
(1990)^{27} \\
\text { prospective* }\end{array}$ & Adults, $\mathrm{n}=7$ & $\begin{array}{l}\text { GA: lorazepam, morphine, sufentanil, } \\
\text { vecuronium, isoflurane }\end{array}$ & $\begin{array}{l}\text {-Isoflurane } 1 \mathrm{MAC} \text { : prolonged the conduction } \\
\text { in both normal pathways and AP }\end{array}$ \\
\hline $\begin{array}{l}\text { Chang }(1996)^{28} \\
\text { retrospective }\end{array}$ & $\begin{array}{l}\text { Infants, children, } \\
\text { adolescents } \\
\mathrm{n}=51\end{array}$ & $\begin{array}{l}\text { Sedation (pethidine, promethazine, } \\
\text { chloropromazine) versus GA with isoflurane }\end{array}$ & $\begin{array}{l}\text {-Compared to sedatives, isoflurane prolonged } \\
\text { the refractory periods in AP (antegrade), atria } \\
\text { and ventricles. } \\
\text {-Isoflurane: interfered with EPS }\end{array}$ \\
\hline $\begin{array}{l}\text { Sharpe }(1994)^{29} \text {, } \\
\text { RCT }\end{array}$ & Adults, $n=21$ & $\begin{array}{l}\text { GA: lorazepam, sufentanil, vecuronium, } \\
\text { volatiles (halothane or isoflurane or enflurane) }\end{array}$ & $\begin{array}{l}\text { - Lorazepam / sufentanil: no effect on AP } \\
\text {-Volatiles: } \uparrow \text { in AV and AP refractoriness } \\
\text { (mostly enflurane) }\end{array}$ \\
\hline $\begin{array}{l}\text { Dobkowski } \\
(1991)^{30} \\
\text { prospective* }\end{array}$ & Adults, $\mathrm{n}=7$ & $\begin{array}{l}\text { GA: lorazepam, morphine, sufentanil, } \\
\text { vecuronium, enflurane }\end{array}$ & $\begin{array}{l}\cdot \text { Enflurane: } \downarrow \mathrm{AV} \text { and AP conduction / } \\
\text { should not be used in WPW patients }\end{array}$ \\
\hline $\begin{array}{l}\text { Tempe }(1997)^{31} \text {, } \\
\text { retrospective }\end{array}$ & Adults, $n=13$ & GA: morphine, halothane, pancuronium & •Halothane: interferes with EPS/ablation \\
\hline $\begin{array}{l}\text { Sharpe }(1999)^{32} \text {, } \\
\text { prospective }\end{array}$ & Adults, $\mathrm{n}=15$ & $\begin{array}{l}\text { GA: midazolam, alfentanil, vecuronium, } \\
\text { sevoflurane }\end{array}$ & $\begin{array}{l}\text {-Sevoflurane: no effect on AV or AP } \\
\text { conduction/ suitable for ablations }\end{array}$ \\
\hline $\begin{array}{l}\text { Pérez }(2008)^{33}, \\
\text { prospective }\end{array}$ & Children, $\mathrm{n}=15$ & $\begin{array}{l}\text { GA: fentanyl, vecuronium, } \\
\text { propofol replaced by sevoflurane }\end{array}$ & $\begin{array}{l}\text {-Sevoflurane: moderate changes in AP } \\
\text { properties/suitable for ablations }\end{array}$ \\
\hline $\begin{array}{l}\text { Gómez-Arnau } \\
(1983)^{34}, \\
\text { prospective }\end{array}$ & Adults, $\mathrm{n}=18$ & $\begin{array}{l}\text { GA: Morphine, thiopental, fentanyl, diazepam, } \\
\mathrm{N}_{2} \mathrm{O} \text {, pancuronium, droperidol }\end{array}$ & $\begin{array}{l}\text {-Droperidol: dose-dependent ?of AP } \\
\text { conduction, } \uparrow \text { antegrade \& retrograde } \\
\text { refractory period } \\
\text {-Induction agents, fentanyl, diazepam: } \\
\text { no effect on AP refractory period }\end{array}$ \\
\hline $\begin{array}{l}\text { Fujii }(2009)^{35} \\
\text { prospective }\end{array}$ & $\begin{array}{l}\text { Children, } \mathrm{n}=27 \\
(9 \mathrm{WPW})\end{array}$ & GA: propofol, fentanyl, vecuronium & $\begin{array}{l}- \text { Fentanyl/propofol combination: } \\
\downarrow \text { SN automaticity }\end{array}$ \\
\hline Fujii $(2011)^{37}, \mathrm{RCT}$ & $\begin{array}{l}\text { Children, } \mathrm{n}=60 \\
(29 \text { completed study) }\end{array}$ & GA: propofol, remifentanil, vecuronium & $\begin{array}{l}- \text { Remifentanil: } \downarrow \text { SN automaticity, } \\
\downarrow \text { SA conduction }\end{array}$ \\
\hline $\begin{array}{l}\text { Niksch }(2010)^{38} \text {, } \\
\text { RCT }\end{array}$ & $\begin{array}{l}\text { Children, adolescents } \\
\mathrm{n}=15 \text { ( } 5 \mathrm{WPW})\end{array}$ & GA: propofol \pm remifentanil & $\begin{array}{l}- \text { Remifentanil: } \downarrow \mathrm{SN} \& \text { AV function - may } \\
\text { affect EPS findings }\end{array}$ \\
\hline $\begin{array}{l}\text { Sharpe }(1992)^{39} \text {, } \\
\text { prospective }\end{array}$ & Adults, $\mathrm{n}=8$ & $\begin{array}{l}\text { GA: lorazepam, alfentanil, midazolam, } \\
\text { vecuronium }\end{array}$ & $\begin{array}{l}\text {-Alfentanil/midazolam anaesthesia: no effect } \\
\text { on AV node or AP conduction }\end{array}$ \\
\hline
\end{tabular}

AP: accessory pathway, AV: atrio-ventricular, EPS: electrophysiological study, GA: general anaesthesia, MAC: minimum alveolar concentration, n: number of patients, RCT: randomised controlled trial, SA: sino-atrial, SN: sinus node, SVT: supraventricular tachycardia, WPW: WolffParkinson-White

* study published in the form of abstract 
refractory period [21]. Fentanyl at doses $30-50 \mu \mathrm{g} / \mathrm{kg}$ was found to exert no effect on the anterograde effective refractory period of the AP [34]. It is the most popular opioid, used in the majority of reported cases, and is described as very safe $[44,49,50,53,54$, $56,58,60,62-64]$. Conversely, the atropine-like effect of pethidine renders it less appropriate for WPW patients [12].

Regarding neuromuscular blockers (NMBs), succinylcholine may act on muscarinic or adrenergic receptors of the sinus node, with bradycardia presenting more often [21]. These effects make the drug less attractive compared to modern non-depolarising NMBs, even though it has been used uneventfully in several cases $[18,48,53,64,69,70]$. Among nondepolarising agents, pancuronium may not exert significant direct effects on APs [34], but enhances AV conduction, increases HR and has triggered SVT in a couple of cases; thus it is suggested to be avoided [44, 45]. Atracurium may cause histamine release and possible autonomic instability [71], while cis-atracurium is devoid of cardiovascular effects and represents a safer choice [21]. Rocuronium has mild vagolytic properties, while vecuronium may cause HR reduction [21]; both have been used safely in WPW patients [53-55, 57].

The reversal of NMB may cause problems, since neostigmine can induce serious tachyarrhythmias by depressing the AV while facilitating AP conduction; Kadoya and collagues reported that $1 \mathrm{mg}$ of neostigmine converted a narrow complex AF to haemodynamically unstable wide complex tachycardia [54]. Additionally, the anticholinergic actions of atropine and glycopyrrolate are undesirable in WPW patients [49-51]. Especially atropine accelerates the conduction and shortens the anterograde and retrograde effective refractory period in the AP [72]. Thus, it seems that the standard anticholinergic/anticholinesterase combination should preferably be omitted $[53,71]$. Alternatively, sugammadex could be used for rocuronium or vecuronium reversal; it seems to exert no significant actions on cholinesterase, nicotinic and muscarinic receptors [73]. Two case reports describe its uneventful use [55, 57].

Sedation with a benzodiazepine/opioid combination can be administered alone or as supplement to local anaesthesia for minor surgical procedures [46]. Among benzodiazepines, diazepam is cardiovascularly stable, without effects on the AP refractory period [34]. Nevertheless, its long duration of action (half life: $43 \mathrm{~h}$ ) is a disadvantage, especially for outpatient cases. The intermediate acting lorazepam (half life: $14 \mathrm{~h}$ ) or the short acting midazolam (half life: $2 \mathrm{~h}$ ) have also been found to exert no significant effects on AP conduction, and represent more attractive choices [32, 39]. They can be safely used in conjunction with fentanyl, alfentanil or sufentanil [21, 39, 46]. Also, droperidol (200-600 $\mu \mathrm{g} / \mathrm{kg}$ ) was found to depress the antegrade and retrograde conduction of the AP in a dose-dependent manner and a fentanyl/droperidol combination was suggested as a useful regimen [34].

When GA is provided, adequate doses of anesthetics and opioids should be given to suppress the sympathetic response to laryngoscopy/tracheal intubation. Supraglottic airway devices should be preferred whenever possible, since their insertion causes less sympathetic stimulation [74], but care should be taken to avoid hypercarbia during spontaneous ventilation. Intraoperatively, deep anaesthesia and sufficient analgesia reduce the stress response to surgical noxious stimuli.

Regional anaesthesia (RA) may be advantageous over GA in terms of avoiding airway manipulation and patient's exposure to multiple drugs with possible proarrhythmic properties. Additionally, RA techniques provide high quality intraoperative and also postoperative analgesia via central neuraxial and peripheral nerve catheters. Nevertheless, caution is needed with the height of sympathetic blockade, because sinus bradycardia and intra-cardiac conduction defects may develop if the thoracic (T1 to T4) cardio-accelerator fibers are blocked. The AV conduction time and functional refractory period may become prolonged and AP conduction facilitated due to unopposed parasympathetic tone $[75,76]$. Cases of WPW syndrome unmasked due to high levels of spinal blocks are not rare, especially if combined with other vagal stimulants $[17,76,77]$. Thoracic epidural and single shot spinal anaesthesia are more likely to cause cardiac sympathectomy, thus careful dosing and increased vigilance for a high blockade are required. The spinal dose of local anaesthesia should ideally produce the minimum level of sensory block required for the surgery. Addition of opioids allows a reduction in local anaesthetic doses $[78,79]$, while selective spinal opioid analgesia may be used in some cases (i.e. labor), thus minimising haemodynamic fluctuations $[78,80]$.

Dose titration and gradual elevation of the block can be achieved with lumbar epidural and combined low-dose-spinal/epidural anaesthesia. These modalities offer more haemodynamic stability and should probably be preferred over single-shot spinal anaesthesia [81]. There are several reports of operations (caesarean deliveries included) performed safely under a simple epidural [64, 82-84] or a combined spinal/epidural anaesthesia [81, 85-88]. In selected cases, combined general/regional anaesthesia may be used; successful thoracotomy under propofol anaesthesia together with thoracic epidural analgesia has been reported [61].

Reduced venous return and atrial filling due to an extensive sympathetic blockade may precipitate arrhythmias. Adequate fluid loading should be con- 
sidered in order to reduce - as possible - the risk and magnitude of hypotension, subsequent sympathetic activation or need for sympathomimetic drugs $[88,89]$. If hypotension occurs, a pure alpha-adrenergic agonist (i.e. phenylephrine) is the vasopressor of choice [88, $90,91]$. The addition of epinephrine to local anaesthetics should be avoided, as it may shorten the AP refractory period and facilitate arrhythmias [43]. Finally, supplementation of any regional technique with adequate sedation in order to reduce anxiety and sympathetic stimulation is advisable [16].

In pregnant patients with WPW, physiological adaptation and emotional factors increase the risk of arrhythmias; estrogens, intravascular volume expansion, haemodynamic changes, pain, stress and oxytocin given during labor may all trigger SVTs, especially when an extended subarachnoid sympathetic block is established $[87,92,93]$. In this regard, a simple epidural or a combined spinal/epidural are the modalities of choice for caesarean delivery. Vaginal delivery has also been accomplished safely in WPW parturients, even in cases with severe co-morbidities, under a carefully managed labor epidural analgesia with local anaesthetic/opioid combination [83, 84]. Regarding oxytocin, it should be omitted if possible [71, 88], since it has been associated with paroxysmal SVT, even in common clinical doses [90].

\section{Management of perioperative arrhythmias}

Orthodromic AVRTs are regular narrow-complex tachycardias (constant R-R intervals, QRS $<120 \mathrm{~ms}$ ) that should be treated as any other paroxysmal SVT with vagal maneuvers, such as carotid sinus massage, Valsalva or Valsalva-like maneuver in case of mechanical ventilation, along with $100 \%$ oxygen [94]. If these measures fail, adenosine IV boluses should be given, starting with $6 \mathrm{mg}$, followed by $12 \mathrm{mg}$ and further $12 \mathrm{mg}$, if tachycardia persists. Adenosine suppresses both sinus automaticity and AV conductivity, and usually converts an SVT to normal SR [90, 95]. It should be given as a rapid push, because of its very fast elimination. Its ultra-short duration of action also renders adenosine suitable for parturients [87, 92], even though it may cause temporary bradycardia to the fetus; thus, fetal HR monitoring is suggested during administration [90].

Beta blockers or more rarely calcium channel blockers have been used to treat WPW-related SVTs [44, 51, 91-94]. Beta blockers can also be given preventively before laryngoscopy [96]. The very short acting esmolol is preferred over long acting agents [44], especially in parturients, even though the risk of causing fetal distress still exists [92].

Both ephedrine and phenylephrine have been used to treat hypotension $[18,81,86,90]$. Moreover, phenylephrine was reported to resolve a paroxysmal
SVT resistance to various other measures and drugs [91].

Antidromic AVRT presents as regular wide-complex tachycardia (QRS > $120 \mathrm{~ms}$ ), sometimes difficult to differentiate from VT [9]. Amiodarone or procainamide can be used to restore the rhythm in haemodynamically stable patients. If there is doubt about the type of arrhythmia, it should be treated as VT [97].

Pre-excited AF presents as irregular wide complex tachycardia, often resembling VF or Torsades de Pointes [97]. Amiodarone (300 mg i.v. in $20 \mathrm{~min}$ ) can be given, while digoxin and verapamil are contraindicated, and also adenosine and diltiazem should be avoided, since they block the AV node while concomitantly facilitating AP conduction, thus increasing the risk of VF $[90,97]$. Procainamide and propranolol can be useful because they prolong the AP refractory period [57]. Expert cardiologic consultation is required in such high risk situations.

Electrical synchronised cardioversion is indicated for SVT or AF resistant to antiarrhythmic drugs or in cases with extreme tachycardia and/or hypotension/ shock, myocardial ischaemia, heart failure/pulmonary oedema or syncope $[17,59,81,97,98]$. Immediate defibrillation should be performed in VF or pulseless VT [97]. Antiarrhythmic drugs and a defibrillator should be prepared before anaesthesia induction $[57,81]$.

Sympathetic stimulation should be avoided: alleviation of anxiety, adequate intraoperative anaesthesia/ analgesia, suppression of response to intubation, avoidance of anticholinergic/sympathomimetic drugs are mandatory [96]. The patient should be kept warm, normovolaemic, normocarbic and balanced regarding the acid base and electrolyte status [51]. Smooth recovery from anaesthesia, sufficient postoperative analgesia, prevention of nausea/vomiting that may cause stress and tachycardia are also important.

A concealed WPW syndrome should be considered in the differential diagnosis of paroxysmal SVTs occurring during anaesthesia. If the syndrome is suspected, cardiological consultation and postoperative ECG Holter should be requested [99]. Appearance of the electrocardiographic WPW pattern after induction of anaesthesia should not necessarily lead to surgery cancellation, especially if the patient has no history of suspicious symptoms and is haemodynamically stable $[100,101]$. Nevertheless, in such cases the anaesthesiologist should be fully prepared to treat any arrhythmias that may arise [99]. It is also important to note that asymptomatic patients with intermittent WPW do not receive antiarrhythmic treatment and generally carry a low risk for tachyarrhythmias [47, 100, 102, 103]. Adequate preparation, invasive blood pressure monitoring, and a high level of vigilance are of paramount importance. 
The identified publications on the anaesthetic management of patients with WPW-syndrome undergoing non-ablative surgical procedures are presented in Table 2.

\section{Other Pre-Excitation Syndromes with different Accessory Pathways}

\section{Mahaim Fibers}

In 1938, I. Mahaim described anatomic connections between the AV node and ventricles [104]. These "Mahaim Fibers" were initially considered to connect the AV node or the His bundle/fascicles with the right ventricle (nodo- or fasciculo-ventricular fibers) [104], but later, it was demonstrated that they usually originated in the right atrium and terminated in the right ventricular wall (atrio-ventricular) or near the right bundle branch (atrio-fascicular) [105]. Mahaim Fibers (MFs) are found in 0.5-1:10 000 of the general population, comprising about the $3 \%$ of APs [106, 107], and may coexist with other cardiovascular pathology, such as Ebstein's anomaly [107].

The MF pathways exhibit longer conduction times compared to the bundle of Kent, while they share some of the AV properties, such as similar conduction velocity, conduction delay at high atrial rates and sensitivity to adenosine [107]. They allow only antegrade conduction and may be part of a circuit with retrograde conduction through the AV node; these antidromic AVRTs are characterized by a wide QRS complex and may be difficult to differentiate from ventricular arrhythmias [107, 108]. Tachycardia with a left bundle brunch block pattern may be seen as the result of right ventricle pre-excitation (stimulated before $L V$ ) via MFs [106]. The ECG may have features of pre-excitation, but usually it has a normal PQ interval and minimal or no delta wave $[106,107]$. An rS pattern in lead III is found in about $60 \%$ of the patients, while an additional suspicious finding is the absence of q wave in lead I [106]. The combination of such an ECG with young age and history of tachyarrhythmias strongly suggests the existence of MFs, but certain diagnosis requires an EPS.

Beta-blockers, class IA and IC antiarrhythmics are used to prevent tachycardias [107], but definite treatment with AP ablation is preferred in many cases [107, 108]. Anaesthetic data on the management of patients with MFs are limited. Conditions and drugs causing sympathetic activation and catecholamine release should be avoided; Zweifler and colleagues suggested that perioperative stress and pain were possibly the triggering factors of a wide complex tachycardia (MF pathway conduction with AV nodal reentry) in a woman with undiagnosed MFs (Table 3) [108].

\section{Lown- Ganong-Levine syndrome}

The Lown-Ganong-Levine (LGL) syndrome is another rare pre-excitation condition first described in 1952 [109]. Its ECG pattern is characterised by a short PQ interval $(<120 \mathrm{~ms})$, a normal or inverted $\mathrm{P}$ wave, and a QRS complex of normal morphology and duration $[109,110]$. The combination of the above features with paroxysmal SVTs is suggestive of LGL syndrome, which comprises the $17 \%$ of cases with short PQ interval [109]. Compared to WPW, it has shorter PJ and PQ intervals which remain constant over the years, while the QRS complex usually has a duration of 80 $\mathrm{ms}$ or less, without the characteristic slurring (i.e. no delta wave) [109].

The short PQ interval reflects a fast conduction of the action potential from atria to ventricles, without the normal delay in the AV node. The involved mechanisms are not quite clear: enhanced $\mathrm{AV}$ conduction may be caused by a congenitally hypoplastic and malfunctioning AV node, which allows atrial impulses to be rapidly conducted to the ventricles [111]. Another possible mechanism is the presence of James or Brechenmacher fibers which bypass - partially or completely - a normal AV node: James fibers connect the upper part of the AV node with its lower part or with the His bundle [112], while the Brechenmacher fibers form a route between the atrium and bundle of His, thus completely bypassing the AV node [113]. In both cases, the avoidance of normal AV delay results in short PQ intervals, while the normal stimulation of ventricles through the His-Purkinje fibers gives normal QRS complexes. The normal and the bypass tract form a circuit for reentry arrhythmias. Atrial flutter, AF and VT may develop, while the deterioration of a paroxysmal AF into VF can cause sudden cardiac death [109, $114,115]$.

The syndrome is mainly diagnosed in women who develop tachyarrhythmias usually in their fourth decade of life $[109,110,116]$. Sympathetic stimulation, changes in cardiac automaticity/conduction, and pregnancyassociated physiologic adaptations may trigger or facilitate SVTs $[109,117]$.

As in WPW, perioperative management of patients with LGL should first aim to minimise possible triggering factors of arrhythmias. Benzodiazepines, such as midazolam or diazepam $[110,116]$, could relieve preoperative anxiety, while drugs with sympathomimetic properties, such as ketamine or pancuromium, should be avoided [65]. Patients should continue their antiarrhythmic medication perioperatively, while beta blockers - especially short acting ones, such as esmolol - could be useful [116]. Episodes of SVT should be managed with vagal maneuvers and adenosine [110].

As shown in Table 3, anaesthetic data are rather limited; thiopental and propofol have been used without 
Table 2. Case reports and series describing the perioperative management, complications and outcome of patients with WPW syndrome undergoing non-ablative procedures

\begin{tabular}{|c|c|c|c|c|c|c|}
\hline $\begin{array}{l}\text { First author } \\
\text { (year) }\end{array}$ & Syndrome & $\begin{array}{l}\text { No of pts- } \\
\text { gender/ } \\
\text { age }\end{array}$ & $\begin{array}{l}\text { Surgery/ } \\
\text { procedure }\end{array}$ & Anaesthesia & $\begin{array}{l}\text { Complications \& } \\
\text { Management }(*)\end{array}$ & Outcome / Remarks \\
\hline $\begin{array}{l}\text { Lustik }^{15} \\
\text { (1999) }\end{array}$ & $\mathrm{WPW}^{\dagger}$ & $1 F / 34 y$ & $\begin{array}{l}\text { Uterus dilation / } \\
\text { evacuation }(17 \mathrm{w})\end{array}$ & $\begin{array}{l}\text { RA } \\
\text { SA (no further details) }\end{array}$ & $\begin{array}{l}\text {-Reported palpitations / } \\
\text { chest pain } \\
\text {-ECG: inferior Q waves } \\
\text { *Cardiologic } \\
\text { consultation }\end{array}$ & $\begin{array}{l}\cdot \text { Uneventful course } \\
\text { •Postop EPS/ RFCA }\end{array}$ \\
\hline $\begin{array}{l}\text { Le Manach }{ }^{16} \\
(2006)\end{array}$ & $\mathrm{WPW} \dagger$ & $1 \mathrm{M} / 67 \mathrm{y}$ & $\begin{array}{l}\text { Abdominal aortic } \\
\text { aneurysm repair }\end{array}$ & $\begin{array}{l}\text { GA } \\
\text { Premed: midazolam. } \\
\text { IN \& MNT: propofol, } \\
\text { sufentanil, atracurium, } \mathrm{N}_{2} \mathrm{O} \text {, } \\
\text { morphine. }\end{array}$ & $\begin{array}{l}\text {-Post-op ECG changes } \\
\text { mimicking inferior MI } \\
\text { *Daily ECG follow-up, } \\
\text { Troponin I } \\
\text { measurements }\end{array}$ & $\begin{array}{l}\text {-Uncomplicated course } \\
\text {-ECG returned to normal }\end{array}$ \\
\hline $\begin{array}{l}\operatorname{Garg}^{17} \\
(2011)\end{array}$ & WPW & $1 \mathrm{M} / 32 \mathrm{y}$ & $\begin{array}{l}\text { Urological } \\
\text { surgery }\end{array}$ & $\begin{array}{l}\text { Spinal: bupivacaine }+ \text { fentanyl. } \\
\text { Upper sensory level: } \mathrm{T} 8 \\
\text { Other drugs: diazepam, } \\
\text { midazolam }\end{array}$ & $\begin{array}{l}\text { Intermittent WPW - } \\
\text { intraop rhythm changes } \\
\text { (HR:70-90) } \\
\text { *none }\end{array}$ & $\begin{array}{l}\text {-Uneventful course / pt } \\
\text { haemodynamic stable } \\
\text {-Vigilance for level of } \\
\text { neuraxial block }\end{array}$ \\
\hline $\begin{array}{l}\mathrm{Naço}^{44} \\
(2009)\end{array}$ & WPW & $1 F / 17 y$ & Thyroidectomy & $\begin{array}{l}\text { GA } \\
\text { IN: Midazolam, fentanyl, } \\
\text { propofol, pancuronium } \\
\text { MNT: halothane }\end{array}$ & $\begin{array}{l}\text {-SVT after pancuronium } \\
\text { / tracheal intubation } \\
\text { *Adenosine, esmolol }\end{array}$ & $\begin{array}{l}\text {-Uneventful course } \\
\text {-Pancuronium may } \\
\text { trigger SVT }\end{array}$ \\
\hline $\begin{array}{l}\text { Richmond } \\
\text { (1988) }\end{array}$ & WPW & $\begin{array}{l}1 \mathrm{M} / 36 \mathrm{w}+ \\
40 \mathrm{w}+\end{array}$ & $\begin{array}{l}\text { 1) IPPV for } \\
\text { pneumonia } \\
\text { 2) Pyloromyotomy }\end{array}$ & $\begin{array}{l}\text { 1) Pancuronium for IPPV } \\
\text { 2) GA with thiopental, } \\
\text { vecuronium, isoflurane, } \mathrm{N}_{2} \mathrm{O} \\
\text {-Wound infiltration: bupivacaine }\end{array}$ & $\begin{array}{l}\text { 1) Prolonged SVT } \\
\text { episode }(289 \mathrm{bpm}) \\
\text { *Sync cardioversion } \\
\text { 2) None }\end{array}$ & Uneventful course \\
\hline $\begin{array}{l}\text { Schmitz } \\
\text { (1997) }\end{array}$ & WPW & $1 F / 26 y$ & $\begin{array}{l}\text { Teeth surgical } \\
\text { removal }\end{array}$ & $\begin{array}{l}\text {-Premed: midazolam / Sedation: } \\
\text { fentanyl, midazolam, } \mathrm{N}_{2} \mathrm{O} \\
\text {-Local anaesthesia (bupivacaine) }\end{array}$ & $\begin{array}{l}\cdot \text { None / Sedation } \\
\text { associated with ECG } \\
\text { normalization }\end{array}$ & Uneventful course \\
\hline $\begin{array}{l}\text { Wakita } \\
(2007)\end{array}$ & $\begin{array}{l}\text { Intermittent } \\
\mathrm{WPW}^{\dagger}\end{array}$ & $1 F / 49 y$ & Tooth extraction & $\begin{array}{l}\text { IV sedation: propofol } \\
\text { Local anaesthesia: lidocaine ( } \pm \\
\text { epinephrine) }\end{array}$ & $\begin{array}{l}\text { Repeated appearance of } \\
\delta \text {-waves }\end{array}$ & $\begin{array}{l}\text {-Uneventful course } \\
\text { •Epinephrine and } \\
\text { autonomic imbalance } \\
\text { implicated in } \delta \text {-waves }\end{array}$ \\
\hline $\begin{array}{l}\text { Okada }^{48} \\
(1990)\end{array}$ & WPW & $1 \mathrm{M} / 29 \mathrm{y}$ & $\begin{array}{l}\text { Maxillary cyst } \\
\text { operation }\end{array}$ & $\begin{array}{l}\text { GA (premed: atropine, } \\
\text { hydroxyzine, pethilorfan) } \\
\text { IN: thiopental, succinylcholine } \\
\text { MNT: enflurane, } \mathrm{N}_{2} \mathrm{O}\end{array}$ & None & Uneventful course \\
\hline $\begin{array}{l}\text { Janes }^{49} \\
(1989)\end{array}$ & WPW & $1 F / 35 y$ & $\begin{array}{l}\text { Laparoscopic } \\
\text { sterilisation }\end{array}$ & $\begin{array}{l}\text { GA (premed: temazepam) } \\
\text { IN: etomidate, fentanyl, } \\
\text { atracurium } \\
\text { MNT: enflurane, } \mathrm{N}_{2} \mathrm{O} \\
\text { RV: glycopyrrolate/neostigmine }\end{array}$ & $\begin{array}{l}\text { Postop retrosternal } \\
\text { discomfort }+ \text { ECG } \\
\text { changes: Glycopyrrolate } \\
\text { suspected }\end{array}$ & $\begin{array}{l}\text {-Uneventful course } \\
\text {-Sympathetic } \\
\text { stimulation should be } \\
\text { avoided }\end{array}$ \\
\hline $\begin{array}{l}\text { Sinha }^{50} \\
(2010)\end{array}$ & $\begin{array}{l}\text { WPW/ } \\
\text { Ebstein's } \\
\text { anomaly/ } \\
\text { MVS }\end{array}$ & $1 F / 23 y$ & $\begin{array}{l}\text { Danielson's } \\
\text { repair \& MVR }\end{array}$ & $\begin{array}{l}\text { GA (premed: diazepam, } \\
\text { morphine) } \\
\text { IN: propofol, fentanyl, } \\
\text { midazolam, vecuronium } \\
\text { MNT: isoflurane }\end{array}$ & $\begin{array}{l}\cdot \mathrm{SVT}(\downarrow \mathrm{BP}) \\
\text { *Adenosine, } \\
\text { amiodarone, IV fluids }\end{array}$ & $\begin{array}{l}\text { Pt discharged with } \\
\text { persistent pre-excitation } \\
\text { on ECG }\end{array}$ \\
\hline $\begin{array}{l}\text { Goldhill } \\
\text { (1988) }\end{array}$ & WPW & $1 \mathrm{M} / 46 \mathrm{w}+$ & $\begin{array}{l}3 \text { surgeries for } \\
\text { VPS and } \\
\text { hydroceles / } 1 \mathrm{CT}\end{array}$ & $\begin{array}{l}\text { GA ( } \pm \text { premed with atropine) } \\
\text { Thiopental, atracurium, } \\
\text { isoflurane, } \mathrm{N}_{2} \mathrm{O}\end{array}$ & $\begin{array}{l}\cdot \text { SVTs } \\
\text { *Vagal stimulation, } \\
\text { propranolol or verapamil }\end{array}$ & Uneventful course \\
\hline $\begin{array}{l}\text { Laloyaux }^{52} \\
(1998)\end{array}$ & $\begin{array}{l}\text { WPW/ } \\
\text { Cantrell's } \\
\text { pentalogy }\end{array}$ & $\begin{array}{l}1 \mathrm{M} / 42 \mathrm{w} \ddagger \\
\& \\
48 \mathrm{w} \ddagger\end{array}$ & $\begin{array}{l}\text { 1) Inguinal hernia } \\
\text { repair } \\
\text { 2) Blalock- } \\
\text { Taussig shunt }\end{array}$ & $\begin{array}{l}\text { 1) GA: halothane / RA: Caudal } \\
\text { with mepivacaine, bupivacaine } \\
\text { 2) GA: sufentanil, pancuronium, } \\
\text { lidocaine, diazepam }\end{array}$ & $\begin{array}{l}\text {-SVT preop / transient } \\
\text { tachycardia intraop } \\
\text { *no extra drugs (already } \\
\text { on digoxin, amiodarone) }\end{array}$ & $\begin{array}{l}\text {-Uneventful recovery/ } \\
\text { Infant died few weeks } \\
\text { later due to unrelated } \\
\text { reason }\end{array}$ \\
\hline $\begin{array}{l}\text { Kumar }^{53} \\
(1986)\end{array}$ & WPW & $1 \mathrm{M} / 30 \mathrm{y}$ & $\begin{array}{l}\text { Lumbar } \\
\text { laminectomy }\end{array}$ & $\begin{array}{l}\text { GA (premed: papaveretum, } \\
\text { hyoscine) } \\
\text { IN: thiopental, succinylcholine } \\
\text { MNT: isoflurane, } \mathrm{N}_{2} \mathrm{O} \text {, } \\
\text { fentanyl, vecuronium }\end{array}$ & None & $\begin{array}{l}\text {-Uneventful course } \\
\text {-Isoflurane + fentanyl: } \\
\text { safe choice } \\
\text {-Vecuronium: safe } \\
\text { choice }\end{array}$ \\
\hline $\begin{array}{l}\text { Kadoya }^{54} \\
(1999)\end{array}$ & $\begin{array}{l}\text { Intermittent } \\
\text { WPW }\end{array}$ & $1 \mathrm{M} / 67 \mathrm{y}$ & $\begin{array}{l}\text { Laryngeal } \\
\text { microsurgery }\end{array}$ & $\begin{array}{l}\text { GA } \\
\text { IN: propofol, fentanyl, } \\
\text { vecuronium } \\
\text { MNT: sevoflurane, } \mathrm{N}_{2} \mathrm{O} \\
\text { RV: Neostigmine without } \\
\text { atropine }\end{array}$ & $\begin{array}{l}\text {-AF with narrow } \mathrm{QRS} \\
\text { after sevoflurane } / \mathrm{N}_{2} \mathrm{O} \\
\text { discontinuation } \\
\text { *none } \\
\text {-AF } 110-180 \mathrm{bpm} \text { (wide } \\
\text { QRS) with } \downarrow \mathrm{BP} \text { after } \\
\text { neostigmine } \\
\text { *Sync cardioversion }\end{array}$ & $\begin{array}{l}\cdot \text { Extubation } \rightarrow \text { ICU } \\
\text { transfer } \rightarrow \text { recovery } \\
\text { uncomplicated } \\
\text { •Avoidance of anti- } \\
\text { cholinesterases }\end{array}$ \\
\hline
\end{tabular}




\begin{tabular}{|c|c|c|c|}
\hline $\begin{array}{l}\text { Şahin } \\
(2015)\end{array}$ & WPW & $1 \mathrm{M} / 51 \mathrm{y}$ & $\begin{array}{l}\text { Inguinal hernia } \\
\text { repair }\end{array}$ \\
\hline
\end{tabular}

$\begin{array}{lll}\text { GA (premed: midazolam) } & \uparrow \text { HR }(108 \mathrm{bpm}) \text { after } & \bullet \text { Uneventful recovery } \\ \text { IN: tramadol, propofol, } & \text { intubation } & \bullet \text { Sugammadex: may be a } \\ \text { rocuronium } & \text { *i.v. remifentanil } & \text { safe choice }\end{array}$

$\begin{array}{llll}\begin{array}{l}\text { Nakamura } \\ \text { (2009) }\end{array} & \begin{array}{l}\text { WPW/ } \\ \text { Ebstein's } \\ \text { anomaly }\end{array} & \begin{array}{l}\mathrm{n}=3 \\ 1 \mathrm{M} / 34 \mathrm{y} \\ 1 \mathrm{M} / 5 \mathrm{~m} \\ 1 \mathrm{~F} / 5 \mathrm{y}\end{array} & \begin{array}{l}\text { Valvuloplasty/ } \\ \text { AP ablation }\end{array} \\ & & 1 \mathrm{~F} / 23 \mathrm{y} & \mathrm{CD}\end{array}$

MNT: sevoflurane $1 \mathrm{MAC}$, air

$\mathrm{RV}$ : sugammadex $2 \mathrm{mg} / \mathrm{kg}$

(2016)

GA with sevoflurane, fentanyl, None midazolam

GA (parturient denied RA) None

IN: fentanyl, propofol

rocuronium

MNT: sevoflurane, $\mathrm{O}_{2}$ /air

$\mathrm{RV}$ : sugammadex $2 \mathrm{mg} / \mathrm{kg}$

\begin{tabular}{|c|c|c|c|}
\hline $\begin{array}{l}\text { Seki }^{58} \\
(1999)\end{array}$ & WPW & $1 F / 29 y$ & $\begin{array}{l}\text { Uterus dilation \& } \\
\text { curettage (missed } \\
\text { abortion) }\end{array}$ \\
\hline $\begin{array}{l}\text { Sato }^{59} \\
(2014)\end{array}$ & $\mathrm{WPW}^{\dagger}$ & $1 \mathrm{M} / 59 \mathrm{y}$ & $\begin{array}{l}\text { Video-assisted } \\
\text { thoracoscopic } \\
\text { lobectomy }\end{array}$ \\
\hline $\begin{array}{l}\text { Yamaguchi }^{60} \\
(1998)\end{array}$ & WPW & $1 \mathrm{M} / 62 \mathrm{y}$ & $\begin{array}{l}\text { Microsurgery of } \\
\text { larynx }\end{array}$ \\
\hline $\begin{array}{l}\text { Kajikawa }^{61} \\
(2001)\end{array}$ & WPW & $1 \mathrm{M} / 57 \mathrm{y}$ & Thoracic surgery \\
\hline $\begin{array}{l}\text { Takayama }^{62} \\
(2000)\end{array}$ & WPW & $1 \mathrm{M} / 55 \mathrm{y}$ & $\begin{array}{l}\text { Minimally } \\
\text { invasive direct } \\
\text { CAB }\end{array}$ \\
\hline $\begin{array}{l}\text { Gupta }^{63} \\
(2013)\end{array}$ & WPW & $1 \mathrm{~F} / 30 \mathrm{y}$ & $\begin{array}{l}\text { Laparoscopic } \\
\text { cholecystectomy }\end{array}$ \\
\hline
\end{tabular}

GA

Premed: midazolam

IN \& MNT: propofol, fentanyl

WPW pattern on ECG/

Propofol caused ECG

normalization / $\delta$-wave returned after propofol discontinuation

GA \& TEA (catheter insertion) 3 SVT episodes

IN: propofol

*Antiarrhythmics: no

MNT: desflurane, remifentanil effect

* Sync cardioversion

GA $\quad \uparrow$ BP after surgical

Premed: atropine, hydroxyzine laryngoscope inserted-

IN \& MNT: propofol, fentanyl stable thereafter

*none

GA \& TEA

Severe hypercapnia

during one lung

ventilation

INT: propofol $(+$

GA None

IN: midazolam, fentanyl,

None

vecuronium

MNT: propofol, fentanyl, $\mathrm{O}_{2} /$ air

(+ diltiazem infusion)

GA

Premed: alprazolam, ranitidine

IN: fentanyl, propofol

MNT: isoflurane, propofol

\begin{tabular}{|c|c|c|c|}
\hline $\begin{array}{l}\text { Klepper }^{64} \\
(1981)\end{array}$ & WPW & $\begin{array}{l}1 \mathrm{~F} / 28 \mathrm{y}, \\
\text { pregnant }\end{array}$ & $\begin{array}{l}\cdot \text { Cardioversion } \\
\left(35^{\mathrm{w}}, 40^{\mathrm{w}}\right) \\
\cdot \mathrm{CD}\left(40^{\mathrm{w}}\right)\end{array}$ \\
\hline $\begin{array}{l}\text { Sadowski }{ }^{65} \\
\text { (1979) }\end{array}$ & $\begin{array}{l}\mathrm{n}=13 \\
11 \mathrm{WPW}\end{array}$ & $31 / 2 y-64 y$ & $\begin{array}{l}-7 \text { bundle division } \\
\text {-4 non-ablative } \\
\text { surgeries }\end{array}$ \\
\hline
\end{tabular}

-GA with fentanyl, thiopental,

succinylcholine, $\mathrm{N}_{2} \mathrm{O}$

-RA: EA for CD (+ oxytocin)

GA

Thiopental, halothane or

enflurane, $\mathrm{N}_{2} \mathrm{O}$, morphine,

pancuronium or d-tubocurarine

\pm diazepam

$\begin{array}{llll}\begin{array}{l}\text { Hannington- } \\ \text { Kiff }^{66} \\ (1968)\end{array} & \mathrm{WPW}^{\dagger} & 1 \mathrm{~F} / 16 \mathrm{y} & \begin{array}{l}\bullet \text { Auditory meatus } \\ \text { enlargement } / \\ \text { tonsillectomy } \\ \text { •Surgical pack } \\ \text { change }\end{array} \\ \begin{array}{l}\text { Campkin }^{67} \\ (1969)\end{array} & \mathrm{WPW} \dagger & 1 \mathrm{M} / 34 \mathrm{y} & \begin{array}{l}\text { Craniotomy \& } \\ \text { clipping } \\ \text { of aneurysm }\end{array}\end{array}$

-GA (premed: hyoscine)

IN: thiopental $4 \mathrm{mg} / \mathrm{kg}$,

succinylcholine

MNT: halothane, $\mathrm{N}_{2} \mathrm{O}$,

tubocurarine

$\mathrm{RV}$ : atropine/neostigmine

-GA with thiopental,

surgery cancelled)

*pt awakening, surgery

postponed, investigation

GA

-Hypotension enhanced

Premed: promazine, atropine

IN: thiopental, succinylcholine

MNT: halothane, $\mathrm{N}_{2} \mathrm{O}$,

ECG changes

tubocurarine

*BP elevation: ECG

changes resolved

$\begin{array}{llll}\begin{array}{l}\text { Van der } \\ \text { Starre } \\ (1978)\end{array} & \text { WPW } \dagger & 1 \mathrm{M} / 22 \mathrm{y} & \text { Knee arthroscopy } \\ & & \\ \text { Suppan }^{70} & \text { WPW } & 1 \mathrm{~F} / 45 \mathrm{y} & \begin{array}{l}\text { Laparoscopic } \\ \text { ligation of the } \\ (1979)\end{array} \\ & & \begin{array}{l}\text { Fallopian } \\ \text { tubes }\end{array}\end{array}$

GA

Episodes of sinus

Premed: atropine, promethazine tachycardia

IN: clemastine, propanidid, *Discontiuation of

succinylcholine

halothane / lidocaine i.v. MNT: halothane, $\mathrm{N}_{2} \mathrm{O}$ / postop transfer to ICU

None

IN: atropine, althesin,

diazepam, succinylcholine,

tubocurarine, pentazocine MNT: althesin, tubocurarine

Avoid drugs that produce tachycardia or negative inotropic effects

-Uneventful / no ECG changes

-Althesin: a possible alternative to thiopental 


\begin{tabular}{|c|c|c|c|c|c|c|}
\hline $\begin{array}{l}\text { Rahul }^{71} \\
(2006)\end{array}$ & WPW & $\begin{array}{l}\mathrm{n}=2 \\
1 \mathrm{M} / 42 \mathrm{y} \\
1 \mathrm{M} / 26 \mathrm{y}\end{array}$ & $\begin{array}{l}\text {-Lower limb } \\
\text { fracture } \\
\cdot \text { Nephrectomy }\end{array}$ & $\begin{array}{l}\text { 1) RA: CSE } \\
\text { SA: hyperbaric bupivacaine } \\
0.5 \%+\text { fentanyl } \\
\text { EA: plain bupivacaine } 0.375 \% \\
\text { infusion + fentanyl bolus } \\
\text { 2) GA (premed: glycopyrrolate) } \\
\text { IN: midazolam, fentanyl, } \\
\text { propofol, vecuronium } \\
\text { MNT: propofol, } \mathrm{N}_{2} \mathrm{O} \text {, vecuronium } \\
\text { RV: glycopyrrolate/neostigmine }\end{array}$ & $\begin{array}{l}\text {-In case } 2(\mathrm{GA}) \text { : } \\
\text { T-wave inversion in } \\
\text { leads I-II-III without } \\
\text { hemodynamic instability } \\
\text { *No treatment }\end{array}$ & $\begin{array}{l}\cdot \text { Uneventful recovery } \\
\cdot \text { ECG normalised (at } \\
24 \text { h postop) } \\
\text {-Probably RA preferable } \\
\text { to GA }\end{array}$ \\
\hline $\begin{array}{l}\text { Shiroyama } \\
\text { (1994) }\end{array}$ & $\begin{array}{l}\text { Intermittent } \\
\mathrm{WPW} \dagger\end{array}$ & $\begin{array}{l}1 \mathrm{pt} / \mathrm{no} \\
\text { further } \\
\text { details }\end{array}$ & No further details & $\begin{array}{l}\text { RA } \\
\text { Spinal, upper sensory level: C6 }\end{array}$ & WPW pattern on ECG & $\begin{array}{l}\cdot \text { ECG normalized in } 3 \mathrm{~d} \\
\cdot \text { High spinal block may } \\
\text { cause } \downarrow \text { AV \& } \uparrow \text { AP } \\
\text { conduction and unmask } \\
\text { intermittent WPW }\end{array}$ \\
\hline $\begin{array}{l}\text { Lubarsky }^{77} \\
(1989)\end{array}$ & $\mathrm{WPW} \dagger$ & $\begin{array}{l}n=2 \\
1 M / 73 y \\
1 M / 14 y\end{array}$ & $\begin{array}{l}\text { 1) Transurethral } \\
\text { resection of } \\
\text { prostate } \\
\text { 2) Circumcision }\end{array}$ & $\begin{array}{l}\text { 1) RA } \\
\text { Premed: pethidine, pento- } \\
\text { barbital, cefazolin } \\
\text { SA with tetracaine } \\
\text { (i.v. diazepam, ephedrine, } \\
\text { phenylephrine as needed) } \\
\text { 2) GA } \\
\text { Diazepam, isoflurane, } \mathrm{N}_{2} \mathrm{O}\end{array}$ & $\begin{array}{l}\text {-Postop wide QRS } \\
\text { complexes (T6 block, } \\
\text { low } \mathrm{Na}^{+} \text {, hypothermia, } \\
\text { nausea) } \\
\text { *furosemide/warm saline } \\
\text {-Wide QRS complexes } \\
\text { after physostigmine for } \\
\text { gagging } \\
\text { *no treatment }\end{array}$ & $\begin{array}{l}\cdot \text { ECG normalized } \\
\text { •WPW unmasked due to } \\
\uparrow \text { vagal tone (nausea, } \\
\text { hypothermia, spinal } \\
\text { block, gagging, } \\
\text { physostigmine) }\end{array}$ \\
\hline $\begin{array}{l}\text { Deviseti }^{79} \\
(2016)\end{array}$ & WPW & $1 \mathrm{~F} / 20 \mathrm{y}$ & $\begin{array}{l}\text { Evacuation of } \\
\text { molar pregnancy }\end{array}$ & $\begin{array}{l}\text {-RA: SA with hyperbaric } \\
\text { bupivacaine } 0.5 \%+\text { fentanyl } \\
\text { Level of sensory block: T8 } \\
\text {-Other drugs: midazolam, } \\
\text { fentanyl, oxytocin }\end{array}$ & None & $\begin{array}{l}\text { Postop transfer to HDU } \\
\text { for monitoring }\end{array}$ \\
\hline $\begin{array}{l}\text { Brizgys }^{80} \\
(1984)\end{array}$ & WPW & $1 F / 19 y$ & VD & $\begin{array}{l}\text { RA } \\
\text { SA: morphine } \\
\text { Pudendal nerve block } \\
\text { (lidocaine) }\end{array}$ & $\begin{array}{l}\text { Transient sinus } \\
\text { tachycardia }(130 \mathrm{bpm}) \\
\text { during delivery } \\
\text { *Monitoring of vital } \\
\text { signs }\end{array}$ & $\begin{array}{l}\text {-Uneventful course } \\
\text {-Intrathecal opioids for } \\
\text { labour analgesia do not } \\
\text { induce sympathetic } \\
\text { block: useful in WPW }\end{array}$ \\
\hline $\begin{array}{l}\text { Namshikar }^{81} \\
\text { (2013) }\end{array}$ & WPW & $\begin{array}{l}n=2 \\
1 F / 30 y \\
1 F / 28 y\end{array}$ & Elective CDs & $\begin{array}{l}\text { CSE } \\
\text { SA: hyperbaric bupivacaine } \\
0.5 \%(1.7-2 \mathrm{~mL}) \\
\text { Postop analgesia: epidural } \\
\text { bupivacaine } 0.1-0.125 \% \pm \\
\text { fentanyl } 50 \mu \mathrm{g} \\
\text { Other drugs: diclofenac, } \\
\text { oxytocin (20 IU infusion) }\end{array}$ & None & $\begin{array}{l}\text {-Uneventful course } \\
\text {-CSE useful and safe }\end{array}$ \\
\hline $\begin{array}{l}\text { Ruiz-Castro }{ }^{82} \\
\text { (1996) }\end{array}$ & $\begin{array}{l}\text { WPW/ MV } \\
\text { prolapse }\end{array}$ & $1 F / 22 y$ & $\mathrm{CD}$ & RA: EA & $\begin{array}{l}\downarrow \text { BP } 45 \text { min after block } \\
\text { *Methoxamine }\end{array}$ & No further incidents \\
\hline $\begin{array}{l}\text { Robinson }^{83} \\
(2000)\end{array}$ & $\begin{array}{l}\text { WPW/ } \\
\text { FHPP }\end{array}$ & $1 F / 29 y$ & $\begin{array}{l}\text { Forceps assisted } \\
\text { VD }\end{array}$ & $\begin{array}{l}\text { RA: EA with } \\
\text { bupivacaine/epinephrine, } \\
\text { fentanyl, morphine }\end{array}$ & None & $\begin{array}{l}\text {-Uneventful course } \\
\text { - Discharge on } 2^{\text {nd }} \\
\text { postnatal day }\end{array}$ \\
\hline $\begin{array}{l}\mathrm{Misa}^{84} \\
(2007)\end{array}$ & $\begin{array}{l}\text { WPW/ } \\
\text { Ebstein's } \\
\text { anomaly }\end{array}$ & $1 F / 25 y$ & $\begin{array}{l}\text { Forceps assisted } \\
\text { VD }\end{array}$ & $\begin{array}{l}\text { RA: EA with bupivacaine, } \\
\text { fentanyl, chloroprocaine, } \\
\text { lidocaine }\end{array}$ & $\begin{array}{l}\text { Mild } \downarrow \text { BP after delivery } \\
* \text { Phenylephrine }\end{array}$ & $\begin{array}{l}\text {-Uneventful course } \\
\text {-Discharge after } 48 \mathrm{~h}\end{array}$ \\
\hline $\begin{array}{l}\text { Tachikawa } \\
\text { (2008) }\end{array}$ & $\begin{array}{l}\text { WPW/ } \\
\text { Ebstein's } \\
\text { anomaly }\end{array}$ & $\begin{array}{l}\text { Not } \\
\text { available }\end{array}$ & $\begin{array}{l}\text { Ankle joint } \\
\text { fracture repair }\end{array}$ & RA: CSE (no further details) & None & Uneventful course \\
\hline $\begin{array}{l}\mathrm{Sahu}^{86} \\
(2011)\end{array}$ & WPW & $1 F / 45 y$ & $\begin{array}{l}\text { Abdominal } \\
\text { hysterectomy }\end{array}$ & $\begin{array}{l}\text { RA: CSE with bupivacaine, } \\
\text { fentanyl } \\
\text { Postop PCEA }\end{array}$ & $\begin{array}{l}\downarrow \text { BP after initial } \\
\text { epidural bolus } \\
* \text { Phenylephrine }\end{array}$ & $\begin{array}{l}\text { Postop ICU for } 24 \mathrm{~h} \\
\text { monitoring }\end{array}$ \\
\hline $\begin{array}{l}\text { Palaria }^{87} \\
(2013)\end{array}$ & WPW & $1 \mathrm{~F} / 30 \mathrm{y}$ & Emergency CD & $\begin{array}{l}\text { RA (CSE) } \\
\text {-SA with hyperbaric bupivacaine } \\
\text {-Postop EA: bupivacaine } \\
\text {-Other drugs: oxytocin }\end{array}$ & None & Uneventful course \\
\hline $\begin{array}{l}\text { Kaur }^{88} \\
(2012)\end{array}$ & WPW & $1 \mathrm{~F} / 30 \mathrm{y}$ & $\mathrm{CD}$ & $\begin{array}{l}\text { RA (CSE) } \\
\text { •SA: hyperbaric bupivacaine } \\
0.5 \%(1.8 \mathrm{ml}) \text { - block up to T8 } \\
\text {-EA: bupivacaine } 0.5 \% \text { - level T5 } \\
\text { •Postop EA: bupivacaine } 0.125 \%\end{array}$ & None & $\begin{array}{l}\text {-Oxytocin was withheld } \\
\text {-Postop transfer to ICU } \\
\text { for } 24 \mathrm{~h} \text { observation }\end{array}$ \\
\hline $\begin{array}{l}\text { Kabade }^{89} \\
(2011)\end{array}$ & WPW & $1 F / 48 y$ & $\begin{array}{l}\text { Abdominal } \\
\text { hysterectomy }\end{array}$ & $\begin{array}{l}\text {-RA: EA with bupivacaine, } \\
\text { lidocaine } \\
\text { •Other drugs: alprazolam, } \\
\text { ranitidine, ondansetron, } \\
\text { midazolam }\end{array}$ & None & $\begin{array}{l}\text {-Uneventful course } \\
\text {-Epidural preferred for } \\
\text { haemodynamic stability } \\
\text { *Prepare defibrillator / } \\
\text { antiarrhythmics }\end{array}$ \\
\hline
\end{tabular}




\begin{tabular}{|c|c|c|c|c|c|c|}
\hline $\begin{array}{l}\text { Shora }^{90} \\
(2007)\end{array}$ & WPW & $\begin{array}{l}n=2 \\
1 F / 28 y \\
1 F / 25 y\end{array}$ & CDs & $\begin{array}{l}\text { RA in both cases } \\
\text {-SA: hyperbaric bupivacaine } \\
\text { (12.5 mg) } \\
\text {-Other drugs: oxytocin }\end{array}$ & $\begin{array}{l}\text { 1. SVT with hypotension } \\
\text { after oxytocin } 5 \mathrm{IU} \\
\text { *Vagal manoeuvres no } \\
\text { effect, phenylephrine for } \\
\text { hypotension, adenosine } \\
\text { terminated SVT } \\
\text { 2. None }\end{array}$ & $\begin{array}{l}\text {-Uneventful course } \\
\text {-Adenosine - under fetal } \\
\text { HR monitoring-is the } \\
\text { first choice in parturients }\end{array}$ \\
\hline $\begin{array}{l}\text { Jacobson }^{91} \\
(1985)\end{array}$ & WPW & $1 \mathrm{M} / 17 \mathrm{y}$ & Eye surgery & $\begin{array}{l}\text { GA (premed: diazepam) } \\
\text { IN: thiopental, fentanyl, } \\
\text { tubocurarine, lidocaine } 100 \mathrm{mg} \text {, } \\
\text { MNT: halothane, fentanyl, } \mathrm{N}_{2} \mathrm{O} \\
\text { RV: edrophonium }\end{array}$ & $\begin{array}{l}2 \mathrm{SVT} \text { episodes with } \downarrow \text { BP } \\
\text { (at induction and postop) } \\
* \mathrm{O}_{2} \text {, carotid sinus } \\
\text { massage, verapamil, } \\
\text { head down position, } \\
\text { edrophonium, } \\
\text { procainamide, sync } \\
\text { cardioversion: no effect } \\
\text { Phenylephrine: effective }\end{array}$ & $\begin{array}{l}\text {-Uneventful course } \\
\text {-Possible triggering } \\
\text { factors of SVT: } \\
\downarrow \text { BP \& reflex } \uparrow \text { HR (at } \\
\text { induction), lidocaine, } \\
\text { postop retching, MVP } \\
\text { *Phenylephrine may be } \\
\text { useful in terminating } \\
\text { paroxysmal SVT }\end{array}$ \\
\hline $\begin{array}{l}\text { Van Zijil } \\
(2001)\end{array}$ & $\mathrm{WPW} \dagger$ & $1 F / 27 y$ & Emergency CD & $\begin{array}{l}\text { RA: SA with hyperbaric } \\
\text { bupivacaine, fentanyl }\end{array}$ & $\begin{array}{l}\text { SVT }(220 \text { bpm }) \text { with ?BP } \\
\text { *Fluids, Valsalva } \\
\text { maneuvre, carotid sinus } \\
\text { massage: no effect } \\
\text { Verapamil: effective }\end{array}$ & $\begin{array}{l}\text {-Pt transferred to ICU } \\
\text {-EPS / RFCA in } 2 \mathrm{~m} \\
\text { - Neonate died due to } \\
\text { unrelated reason } \\
\text {-Caution with SA }\end{array}$ \\
\hline $\begin{array}{l}\text { Okamoto }{ }^{93} \\
(2003)\end{array}$ & WPW & $1 F / 36 y$ & $\mathrm{CD}$ & RA: EA with mepivacaine & $\begin{array}{l}\text { 4 SVT episodes } \\
\text { *Valsalva maneuvre, ca- } \\
\text { rotid massage: no effect } \\
\text { Verapamil,dysopyramide: } \\
\text { effective }\end{array}$ & $\begin{array}{l}\text {-Verapamil, } \\
\text { dysopyramide: effective } \\
\text {-Oxytocin, pain, anxiety, } \\
\text { may trigger SVT }\end{array}$ \\
\hline $\begin{array}{l}\text { Bronheim } \\
\text { (1992) }\end{array}$ & WPW & $1 \mathrm{M} / 51 \mathrm{y}$ & Surgical ablation & $\begin{array}{l}\text { GA (premed: morphine, } \\
\text { scopolamine) } \\
\text { IN: fentanyl, midazolam, } \\
\text { pancuronium, metocurine. } \\
\text { MNT: enflurane }\end{array}$ & $\begin{array}{l}\text { Paroxysmal SVT after } \\
\text { pericardium } \\
\text { manipulation } \\
\text { *Adenosine: effective }\end{array}$ & $\begin{array}{l}\text {-Further procedure } \\
\text { uneventful } \\
\text {-Adenosine is effective } \\
\text { in WPW syndrome }\end{array}$ \\
\hline $\begin{array}{l}\text { Jones }^{96} \\
(1984)\end{array}$ & WPW & $\begin{array}{l}\mathrm{n}=3 \\
(1 \mathrm{WPW}) \\
1 \mathrm{~F} / 72 \mathrm{y}\end{array}$ & Cholecystectomy & $\begin{array}{l}\text { Propranolol before anaesthesia } \\
\text { IN: thiopental, fentanyl, } \\
\text { alcuronium } \\
\text { MNT: enflurane, } \mathrm{N}_{2} \mathrm{O} \\
\text { RV: glycopyrrolate/ neostigmine }\end{array}$ & None & $\begin{array}{l}\text {-Uneventful course } \\
\text { •Prophylactic } \\
\text { propranolol before } \\
\text { laryngoscopy may be } \\
\text { helpful }\end{array}$ \\
\hline $\begin{array}{l}\text { Wheeler } \\
(2002)\end{array}$ & $\mathrm{WPW} \dagger$ & $1 \mathrm{M} / 72 \mathrm{y}$ & CABG & GA & $\begin{array}{l}\text { Postop wide / narrow } \\
\text { QRS tachy } \\
\text { *Adenosine, } \\
\text { amiodarone: no effect } \\
\text { Sync cardioversion: } \\
\text { effective, then sotalol }\end{array}$ & $\begin{array}{l}\cdot \text { Hospitalized for } 16 \\
\text { days } \\
\text {-Tachy episodes after } \\
\text { discharge } \\
\text { •EPS / ablation } 3 \text { months } \\
\text { later }\end{array}$ \\
\hline $\begin{array}{l}\text { Nishikawa }^{99} \\
(1993)\end{array}$ & $\mathrm{WPW} \dagger$ & $1 \mathrm{M} / 50 \mathrm{y}$ & $\begin{array}{l}\text { Transurethral } \\
\text { resection of } \\
\text { bladder tumor }\end{array}$ & $\begin{array}{l}\text { RA } \\
\text { •Premed: secobarbitone } \\
\text {-SA: tetracaine } \\
\text { •Obturator nerve block with } \\
\text { lidocaine }\end{array}$ & $\begin{array}{l}\cdot \text { Electrical stimulation } \\
\text { for block triggered } \\
\text { paroxysmal tachycardia } \\
\text { *spontaneous resolution } \\
\cdot 2 \text { similar episodes } \\
\text { without haemodynamic } \\
\text { instability } \\
\text { *midazolam }\end{array}$ & $\begin{array}{l}\text {-Uncomplicated course } \\
\text { - Postop Holter } \\
\text { suggested for possible } \\
\text { concealed WPW }\end{array}$ \\
\hline $\begin{array}{l}\text { Chhabra }^{100} \\
(2003)\end{array}$ & WPW $\dagger$ & $1 \mathrm{M} / 15$ & $\begin{array}{l}\text { Modified radical } \\
\text { mastoidectomy }\end{array}$ & $\begin{array}{l}\text { GA } \\
\text { IN: pethidine, thiopental, } \\
\text { vecuronium } \\
\text { MNT: halothane, } \mathrm{N}_{2} \mathrm{O} \\
\text { RV: glycopyrrolate / neostigmine }\end{array}$ & $\begin{array}{l}\text { WPW pattern, but } \\
\text { haemodynamically } \\
\text { stable } \\
\text { *Switch to isoflurane, } \\
\text { lidocaine i.v. (no effect) }\end{array}$ & $\begin{array}{l}\text {-Surgery continued and } \\
\text { completed uneventfully } \\
\text { • Normal SR after } \\
\text { extubation / discharge } \\
\text { after cardiac evaluation }\end{array}$ \\
\hline $\begin{array}{l}\text { Esenther }^{101} \\
(2015)\end{array}$ & $\begin{array}{l}\text { Intermittent } \\
\mathrm{WPW}_{\dagger}^{\dagger}\end{array}$ & $1 \mathrm{M} / 4 \mathrm{y}$ & $\begin{array}{l}\text { Elective } \\
\text { bronchoscopy }\end{array}$ & $\begin{array}{l}\mathrm{GA} \\
\text { Sevoflurane, } \mathrm{N}_{2} \mathrm{O}\end{array}$ & $\begin{array}{l}\text { Intermittent tachy- } \\
\text { arrhythmia haemody- } \\
\text { namically stable } \\
\text { *None }\end{array}$ & $\begin{array}{l}\text {-Uneventful course } \\
\text { •ECG diagnosis of } \\
\text { intermittent WPW }\end{array}$ \\
\hline $\begin{array}{l}\text { Braun }^{103} \\
(1996)\end{array}$ & $\begin{array}{l}\text { Intermittent } \\
\text { WPW/ iso- } \\
\text { rhythmic AV } \\
\text { dissociation } \\
\text { (after } \\
\text { modified } \\
\text { Fontan } \\
\text { operation) }\end{array}$ & $1 \mathrm{~F} / 30 \mathrm{y}$ & $\mathrm{CD}$ & $\begin{array}{l}\text { GA } \\
\text { (RA not preferred because pt } \\
\text { was receiving heparin SC) } \\
\text { IN: etomidate, succinylcholine } \\
\text { MNT: halothane, fentanyl, } \\
\text { midazolam, } \mathrm{N}_{2} \mathrm{O}\end{array}$ & None & $\begin{array}{l}\text {-Uneventful course } \\
\text { (Main focus of paper on } \\
\text { the management of post- } \\
\text { Fontan parturients) }\end{array}$ \\
\hline
\end{tabular}

AF: atrial fibrillation, AP: accessory pathway, AV: atrio-ventricular, BP: blood pressure, bpm: beats per minute, CA(B)G: coronary artery (bypass) graft, CD: caesarean delivery, CSE: combined spinal-epidural anaesthesia, CT: computerized tomography, EA: epidural anaesthesia/ analgesia, ECG: electrocardiogram, EPS: electrophysiological study, F: female, FHPP: familial hypokalaemic periodic paralysis, GA: general anesthesia, HR: heart rate, HDU: high dependency unit, ICU: intensive care unit, IPPV: intermittent positive-pressure ventilation, IN: 
induction, M: male gender, m: months, MAC: minimum alveolar concentration, MI: myocardial infarction, MNT: maintenance, MVS: mitral valve stenosis, MVR: mitral valve repair, NMT: neuromuscular transmission monitoring, PC(E)A: patient controlled (epidural) analgesia, Premed: premedication, Preop: preoperatively, Postop: postoperatively, pt(s): patient(s), RA: regional anaesthesia, RFCA: radiofrequency catheter ablation, RV: reversal of neuromuscular blockade, SA: spinal anaesthesia, SC: subcutaneously, SR: sinus rhythm, SVT: supraventricular tachycardia, Sync cardioversion: synchronized electrical cardioversion, TEA: thoracic epidural anaesthesia/analgesia, $\dagger$ : undiagnosed, VD: vaginal delivery, VPS: ventriculo-peritoneal shunting, wł: weeks (post-conceptual age), WPW: Wolff-Parkinson-White, y: years

Table 3. Publications on perioperative management, complications and outcome of patients with rare pre-excitation syndromes: Mahaim fiber and Lown-Ganong-Levine syndrome

\begin{tabular}{|c|c|c|c|c|c|c|}
\hline $\begin{array}{l}\text { First } \\
\text { author } \\
\text { (publication } \\
\text { year) }\end{array}$ & $\begin{array}{l}\text { Syndrome - } \\
\text { clinical } \\
\text { description }\end{array}$ & $\begin{array}{l}\text { No of } \\
\text { pts - } \\
\text { Sex/ } \\
\text { Age }\end{array}$ & $\begin{array}{l}\text { Type of } \\
\text { surgery }\end{array}$ & Type of anaesthesia / Drugs used & $\begin{array}{l}\text { Complications / } \\
\text { *Management }\end{array}$ & $\begin{array}{l}\text { Outcome / } \\
\text { Points of interest }\end{array}$ \\
\hline $\begin{array}{l}\text { Sadowski }^{65} \\
(1979)\end{array}$ & $\begin{array}{l}\text { In total: } n=13 \\
\text { LGL: } n=2 \\
1 \text { case } L G L \dagger\end{array}$ & $\begin{array}{l}\cdot 31 \mathrm{y} \\
\cdot 51 \mathrm{y} \dagger\end{array}$ & $\begin{array}{l}\text { 1) bundle } \\
\text { division } \\
\text { 2) } 2 \text { other } \\
\text { operations }\end{array}$ & $\begin{array}{l}\text { 1) } \mathrm{GA} \text { : enflurane, } \mathrm{N}_{2} \mathrm{O} \text {, } \\
\text { d-tubocurarine } \\
\text { 2) } \mathrm{GA} \text { : morphine, } \mathrm{N}_{2} \mathrm{O} \text {, pancuronium } \\
\text { or d-tubocurarine }\end{array}$ & $\begin{array}{l}\text { 1) None } \\
\text { 2) Arrhythmia in first } \\
\text { surgery } \rightarrow \text { diagnosis of LGL } \\
\text { *Sync cardioversion }\end{array}$ & $\begin{array}{l}\text {-Uneventful course } \\
\text {-Pancuronium: may cause } \\
\text { tachyarrhythmias }\end{array}$ \\
\hline $\begin{array}{l}\text { Zweifler }^{108} \\
\text { (2011) }\end{array}$ & $\begin{array}{l}\text { Mahaim } \\
\text { fiber } \dagger\end{array}$ & $\begin{array}{l}1 \mathrm{~F} / \\
38 \mathrm{y}\end{array}$ & $\begin{array}{l}\text { Spinal } \\
\text { surgery }\end{array}$ & $\begin{array}{l}\text { Plan for GA } \\
\text { Premed in OR: midazolam, fentanyl }\end{array}$ & $\begin{array}{l}\text { After premed: } \uparrow \text { HR }(180 \\
\text { bpm) - wide QRS - varying } \\
\text { morphology } \\
\text { *Lidocaine: SR restoration }\end{array}$ & $\begin{array}{l}\text {-12-lead ECG: T-wave } \\
\text { inversion } \\
\text {-Surgery postponed / EPS } \\
\text { \& AP ablation / surgery: } \\
\text { 2w later }\end{array}$ \\
\hline $\begin{array}{l}\text { Sharma } \\
(2011)\end{array}$ & LGL & $\begin{array}{l}1 F / \\
42 y\end{array}$ & $\begin{array}{l}\text { Cholecystec- } \\
\text { tomy }\end{array}$ & $\begin{array}{l}\text { GA \& EA (lumbar) for postop } \\
\text { analgesia } \\
\text { IN: midazolam, propofol, fentanyl, } \\
\text { vecuronium } \\
\text { MNT: TIVA with propofol } \\
\text { RV: glycopyrrolate/neostigmine }\end{array}$ & $\begin{array}{l}1 \text { episode of SVT } \\
* \text { carotid sinus massage }\end{array}$ & $\begin{array}{l}\text { - Uneventful course } \\
\text { - TIVA with propofol \& } \\
\text { adequate postop analgesia } \\
\text { may be useful }\end{array}$ \\
\hline $\begin{array}{l}\text { Jones }^{116} \\
(1984)\end{array}$ & $\begin{array}{l}\text { In total: } \mathrm{n}=3 \\
\text { LGL: } \mathrm{n}=1\end{array}$ & $\begin{array}{l}1 \mathrm{~F} / \\
36 \mathrm{y}\end{array}$ & Mastectomy & $\begin{array}{l}\text { GA / premed: diazepam, continuation } \\
\text { of medication (verapamil) }+ \\
\text { propranolol } \\
\text { IN: thiopental, fentanyl, alcuronium } \\
\text { MNT: enflurane, } \mathrm{N}_{2} \mathrm{O} \\
\text { RV: glycopyrrolate/neostigmine }\end{array}$ & None & $\begin{array}{l}\text {-Propranolol may be } \\
\text { useful for prophylaxis, } \\
\text { but caution when } \\
\text { combined with drugs like } \\
\text { verapamil (enhanced } \\
\text { effect) }\end{array}$ \\
\hline
\end{tabular}

AP: accessory pathway, bpm: beats per minute, EA: epidural anaesthesia/analgesia, ECG: electrocardiogram, EPS: electrophysiological study, F: female, GA: general anaesthesia, HR: heart rate, IN: induction, intraop: intraoperatively, LGL: Lown-Ganong-Levine, M: male, MNT: maintenance, No of pts: number of patients, OR: operating room, Premed: premedication, Preop: preoperatively, Postop: postoperatively, Pts: patients, RV: reversal of neuromuscular blockade, SR: sinus rhythm, SVT: supraventricular tachycardia, Sync cardioversion: synchronised electrical cardioversion, TIVA: total intravenous anaesthesia

No of pts: number of patients, $\uparrow$ : disease undiagnosed, *: management of complication

problems for anaesthesia induction in two cases [110, 116]. Total i.v. anaesthesia with propofol may reduce the risk of tachyarrhythmias throughout surgery; furthermore, propofol has been reported to successfully terminate paroxysmal SVTs $[110,118]$. Additionally, since a short PQ interval may be found in conditions such as Duschenne muscular dystrophy [119], the risk of malignant hyperthermia (MH) should probably be considered, especially in children. In this regard, succinylcholine or inhalational agents should be avoided, although a couple of reports do not describe problems with enflurane administration in adults with LGL syndromes $[65,116]$. Modern non-depolarising NMBs exhibit a safe profile, while reversal with gycopyrrolate/ neostigmine was uneventful in two cases $[110,116]$.

Limitations. In the present review, we mainly used information from retrospective and observational studies, case series and reports, while - as expected data from RTCs were limited. Different study designs and populations may account for some contradictory findings, although we consider that safe conclusions could be drawn for most anaesthetics used in WPW. For the more rare pre-excitation conditions, data were rather limited, since only a small number of case reports were identified. Nonetheless, we think that the present review may contribute to a better understanding of pre-excitation syndromes and provide useful information for their perioperative management.

\section{Conclusion}

Anaesthesia and perioperative care of patients with pre-excitation syndromes may be difficult, especially if they are undiagnosed, under-treated or if there is no adequate time for clinical optimisation, as in emergencies. These patients are at a high risk of developing life-threatening arrhythmias perioperatively. Close cooperation with a cardiologist is mandatory, 
while increased vigilance and postoperative cardiovascular monitoring will allow prompt therapeutic intervention in cases of arrhythmias.

\section{Conflict of interest}

Nothing to declare

\section{References}

1. Kent AF. Researches on the structure and function of the mammalian heart. J Physiol 1893; 14: 233-254

2. Wolff L, Parkinson J, White PD. Bundle-branch block with short P-R interval in healthy young people prone to paroxysmal tachyardia. Am Heart J 1930; 5: 685-704. doi: 10.1016/S00028703(30)90086-5

3. Scheinman MM. History of Wolff-Parkinson-White syndrome. Pacing Clin Electrophysiol 2005; 28: 152-156. doi: 10.1111/ j.1540-8159.2005.09461.x

4. Prystowsky EN. Diagnosis and management of the preexcitation syndromes. Curr Probl Cardiol 1988; 13: 225-310. doi: 10.1016/ 0146-2806(88)90025-4

5. Öhnell RF. Pre-excitation, cardiac abnormality, pathophysiological, patho-anatomical and clinical studies of excitatory spread phenomenon bearing upon the problem of the WPW (Wolff, Parkinson, and White) electrocardiogram and paroxysmal tachycardia. Acta Med Scand 1944; 152: 1-167

6. Mark DG, Brady WJ, Pines JM. Preexcitation syndromes: diagnostic consideration in the ED. Am J Emerg Med 2009; 27: 878-888. doi: 10.1016/j.ajem.2008.06.013

7. Gallagher JJ, Pritchett EL, Sealy WC, Kasell J, Wallace AG. The preexcitation syndromes. Prog Cardiovasc Dis 1978; 20: 285 327. doi: 10.1016/0033-0620(78)90015-4

8. Wellens HJ, Brugada P, Penn OC. The management of preexcitation syndromes. JAMA 1987; 257: 2325-2333. doi: 10.1001/ jama.1987.03390170081032

9. Keating L, Morris FP, Brady WJ. Electrocardiographic features of Wolff-Parkinson-White syndrome. Emerg Med J 2003; 20: 491-493. doi: 10.1136/emj.20.5.491

10. Al-Khatib SM, Pritchett ELC. Clinical features of WolffParkinson-White syndrome. Am Heart J 1999; 138: 403-413. doi: 10.1016/S0002-8703(99)70140-7

11. Gollob MH, Green MS, Tang AS, Gollob T, Karibe A, Ali Hassan AS, et al. Identification of a gene responsible for familial WolffParkinson-White syndrome. N Engl J Med 2001; 344: 1823 1831. doi: 10.1056/NEJM200106143442403

12. Bengali R, Wellens HJ, Jiang Y. Perioperative management of the Wolff-Parkinson-White syndrome. J Cardiothorac Vasc Anesth 2014; 28: 1375-1386. doi: 10.1053/j.jvca.2014.02.003

13. Blomström-Lundqvist C, Scheinman MM, Aliot EM, Alpert JS, Calkins H, Camm AJ, et al.; European Society of Cardiology Committee, NASPE-Heart Rhythm Society. ACC/AHA/ESC guidelines for the management of patients with supraventricular arrhythmias - executive summary: a report of the American college of cardiology/American heart association task force on practice guidelines and the European society of cardiology committee for practice guidelines (writing committee to develop guidelines for the management of patients with supraventricular arrhythmias) developed in collaboration with NASPE-Heart Rhythm Society. J Am Coll Cardiol 2003; 42: 1493-1531. doi: 10.1016/j.jacc.2003.08.013
14. Chang RK, Wetzel GT, Shannon KM, Stevenson WG, Klitzner TS. Age- and anesthesia-related changes in accessory pathway conduction in children with Wolff-Parkinson-White syndrome. Am J Cardiol 1995; 76: 1074-1076. doi: 10.1016/S00029149(99)80303-8

15. Lustik SJ, Wojtczak J, Chhibber AK. Wolff-Parkinson-White syndrome simulating inferior myocardial infarction in a cocaine abuser for urgent dilation and evacuation of the uterus. Anesth Analg 1999; 89: 609-612. doi: 10.1213/00000539-19990900000012

16. Le Manach Y, Charbucinska K, Godet G. Accessory myocardial pathway mimicking an inferior myocardial infarction after major vascular surgery. Eur J Anaesthesiol 2006; 23: 527-529. doi: $10.1017 / \mathrm{S} 0265021506210755$

17. Garg R, Sinha R, Nishad P. Patient with Wolff-Parkinson-White syndrome with intermittent pre-excitation under subarachnoid block for urological surgery. Indian J Anaesth 2011; 55: 167170. doi: 10.4103/0019-5049.79899

18. Irish CL, Murkin JM, Guiraudon GM. Anaesthetic management for surgical cryoablation of accessory conducting pathways: a review and report of 181 cases. Can J Anaesth 1988; 35: 634640. doi: 10.1007/BF03020354

19. Joung B, Lee M, Sung JH, Kim JY, Ahn S, Kim S. Pediatric radiofrequency catheter ablation: sedation methods and success, complication and recurrence rates. Circ J 2006; 70: 278-284. doi: $10.1253 /$ circj. 70.278

20. Moore JP, Kannankeril PJ, Fish FA. Isoproterenol administration during general anesthesia for the evaluation of children with ventricular preexcitation. Circ Arrhythm Electrophysiol 2011; 4: 73-78. doi: 10.1161/CIRCEP.110.958660

21. Staikou C, Chondrogiannis K, Mani A. Perioperative management of hereditary arrhythmogenic syndromes. Br J Anaesth 2012; 108: 730-744 (doi: 10.1093/bja/aes105), and supplemental material (Table S1: Effects of commonly used anaesthetic drugs on cardiac electrophysiology)

22. Sharpe MD, Dobkowski WB, Murkin JM, Klein G, Yee R. Propofol has no direct effect on sinoatrial node function or on normal atrioventricular and accessory pathway conduction in Wolff-Parkinson-White syndrome during alfentanil/midazolam anesthesia. Anesthesiology 1995; 82: 888-895. doi: 10.1097/ 00000542-199504000-00011

23. Pappone C, Manguso F, Santinelli R, Vicedomini G, Sala S, Paglino G, et al. Radiofrequency ablation in children with asymptomatic Wolff-Parkinson-White Syndrome. N Engl J Med 2004; 351: 1197-1205. doi: 10.1056/NEJMoa040625

24. Hino H, Oda Y, Yoshida Y, Suzuki T, Shimada M, Nishikawa K. Electrophysiological effects of desflurane in children with WolffParkinson-White syndrome: a randomized crossover study. Acta Anaesthesiol Scand 2018; 62: 159-166. doi: 10.1111/aas.13023

25. Lavoie J, Walsh EP, Burrows FA, Laussen P, Lulu JA, Hansen DD. Effects of propofol or isoflurane anesthesia on cardiac conduction in children undergoing radiofrequency catheter ablation for tachydysrhythmias. Anesthesiology 1995; 82: 884887. doi: $10.1097 / 00000542-199504000-00010$

26. Erb TO, Kanter RJ, Hall JM, Gan TJ, Kern FH, Schulman SR. Comparison of electrophysiologic effects of propofol and isoflurane-based anesthetics in children undergoing radiofrequency catheter ablation for supraventricular tachycardia. Anesthesiology 2002; 96: 1386-1394. doi: 10.1097/00000542200206000-00018

27. Dobkowski WB, Murkin JM, Sharpe MD, Sharma AD, Yee R, Guiraudon G. The effect of isoflurane (1 MAC) on the normal 
AV conduction system and accessory pathways. Anesth Analg 1990; 70: S86. doi: 10.1213/00000539-199002001-00086

28. Chang RK, Stevenson WG, Wetzel GT, Shannon K, Baum VC, Klitzner TS. Effects of isoflurane on electrophysiological measurements in children with the Wolff-Parkinson-White syndrome. Pacing Clin Electrophysiol 1996; 19: 1082-1088. doi: 10.1111/j.1540-8159.1996.tb03417.x

29. Sharpe MD, Dobkowski WB, Murkin JM, Klein G, Guiraudon G, Yee R. The electrophysiologic effects of volatile anesthetics and sufentanil on the normal atrioventricular conduction system and accessory pathways in Wolff-Parkinson-White syndrome. Anesthesiology 1994; 80: 63-70. doi: 10.1097/00000542199401000-00013

30. Dobkowski WB, Murkin JM, Sharpe MD, Molotiu N, Guiraudon G, Yee R. The effect of enflurane (1 MAC) on the normal AV conduction system and accessory pathways. Anesth Analg 1991; 72: $\mathrm{S} 50$

31. Tempe DK, Joshi N, Mehta N, Khanna SK, Banerjee A, Tyagi S. Anaesthetic management of patients undergoing surgery for tachyarrhythmias. Initial experience with 16 patients. Indian Heart J 1997; 49: 173-178

32. Sharpe MD, Cuillerier DJ, Lee JK, Basta M, Krahn AD, Klein GJ, et al. Sevoflurane has no effect on sinoatrial node function or on normal atrioventricular and accessory pathway conduction in Wolff-Parkinson-White syndrome during alfentanil/ midazolam anesthesia. Anesthesiology 1999; 90: 60-65. doi: 10.1097/00000542-199901000-00010

33. Pérez ER, Bartolomé FB, Carretero PS, Fernández CS, Mateos EJ, Tarlovsky LG. Electrophysiological effects of sevoflurane in comparison with propofol in children with Wolff-ParkinsonWhite syndrome. Rev Esp Anestesiol Reanim 2008; 55: 26-31. doi: 10.1016/S0034-9356(08)70494-8

34. Gómez-Arnau J, Márquez-Montes J, Avello F. Fentanyl and droperidol effects on the refractoriness of the accessory pathway in the Wolff-Parkinson-White syndrome. Anesthesiology 1983; 58: 307-313. doi: 10.1097/00000542-198304000-00002

35. Fujii K, Iranami H, Nakamura Y, Hatano Y. Fentanyl added to propofol anesthesia elongates sinus node recovery time in pediatric patients with paroxysmal supraventricular tachycardia. Anesth Analg 2009; 108: 456-460. doi: 10.1213/ ane. $0 \mathrm{~b} 013 \mathrm{e} 31819002 \mathrm{~d} 4$

36. Zaballos M, Jimeno C, Almendral J, Atienza F, Patiño D, Valdes E, et al. Cardiac electrophysiological effects of remifentanil: study in a closed-chest porcine model. Br J Anaesth 2009; 103: 191-198. doi: 10.1093/bja/aep131

37. Fujii K, Iranami H, Nakamura Y, Hatano Y. High-dose remifentanil suppresses sinoatrial conduction and sinus node automaticity in pediatric patients under propofol-based anesthesia. Anesth Analg 2011; 112: 1169-1173. doi: 10.1213/ ANE.0b013e318210f4ef

38. Niksch A, Liberman L, Clapcich A, Schwarzenberger JC, Silver ES, Pass RH. Effects of remifentanil anesthesia on cardiac electrophysiologic properties in children undergoing catheter ablation of supraventricular tachycardia. Pediatr Cardiol 2010; 31: 1079-1082. doi: 10.1007/s00246-010-9768-8

39. Sharpe MD, Dobkowski WB, Murkin JM, Klein G, Guiraudon G, Yee R. Alfentanil-midazolam anaesthesia has no electrophysiological effects upon the normal conduction system or accessory pathways in patients with Wolff-Parkinson-White syndrome. Can J Anaesth 1992; 39: 816-821. doi: 10.1007/BF03008294

40. Hammer GB, Drover DR, Cao H, Jackson E, Williams GD, Ramamoorthy $\mathrm{C}$, et al. The effects of dexmedetomidine on cardiac electrophysiology in children. Anesth Analg 2008; 106: 79-83. doi: 10.1213/01.ane.0000297421.92857.4e

41. Tirotta CF, Nguyen T, Fishberger S, Velis E, Olen M, Lam L, et al. Dexmedetomidine use in patients undergoing electrophysiological study for supraventricular tachyarrhythmias. Paediatr Anaesth 2017; 27: 45-51. doi: 10.1111/pan.13019

42. Vazir-Marino F, Young ML, Kohli V, Barron M, Wolff GS. Controlled ventilation enhances catheter stability during radiofrequency ablation. Pacing Clin Electrophysiol 1999; 22: 86-90. doi: 10.1111/j.1540-8159.1999.tb00304.x

43. Wellens HJJ, Brugada P, Roy D, Weiss J, Bär FW. Effect of isoproterenol on the anterograde refractory period of the accessory pathway in patients with the Wolff-Parkinson-White syndrome. Am J Cardiol 1982; 50: 180-184. doi: 10.1016/00029149(82)90026-1

44. Naço M, Çeliku E, Llukaçaj A, Shehaj J, Kameniku R. Toxic adenoma of the thyroid gland and Wolff-Parkinson-White syndrome. Hippokratia 2009; 13: 116-118

45. Richmond MN, Conroy PT. Anesthetic management of a neonate born prematurely with Wolff Parkinson White syndrome. Anesth Analg 1988; 67: 477-478

46. Schmitz JP, Holmgreen WC. Outpatient anesthetic management of a patient with Wolff-Parkinson-White syndrome. J Oral Maxillofac Surg 1997; 55: 175-179. doi: 10.1016/S02782391(97)90239-1

47. Wakita R, Takahashi M, Ohe C, Kohase H, Umino M. Occurrence of intermittent Wolff-Parkinson-White syndrome during intravenous sedation. J Clin Anesth 2008; 20: 146-149. doi: 10.1016/j.jclinane.2007.06.025

48. Okada H, Satoh A, Hara T, Matsukawa N. An experience of anesthesia in a case of WPW syndrome. Ou Daigaku Shigakushi 1990; 17: 198-202

49. Janes EF, Wilkinson K. Wolff-Parkinson-White syndrome and ECG after operation. Anaesthesia 1989; 44: 355-356. doi: 10.1111/j.1365-2044.1989.tb11298.x

50. Sinha PK, Kumar B, Varma PK. Anesthetic management for surgical repair of Ebstein's anomaly along with coexistent WolffParkinson-White syndrome in a patient with severe mitral stenosis. Ann Card Anaesth 2010; 13: 154-158. doi: 10.4103/ 0971-9784.62934

51. Goldhill DR, Latosa ED, Facer E. Anaesthesia and WolffParkinson-White syndrome during infancy: a review. J R Soc Med 1988; 81:345-347. doi: 10.1177/014107688808100616

52. Laloyaux P, Veyckemans F, Van Dyck M. Anaesthetic management of a prematurely born infant with Cantrell's pentalogy. Paediatr Anaesth 1998; 8: 163-166. doi: 10.1046/j.14609592.1998.00687.x

53. Kumar CM. Wolff-Parkinson-White syndrome and general anaesthesia: use of isoflurane and vecuronium. Br J Anaesth 1986; 58: 574-575. doi: 10.1093/bja/58.5.574

54. Kadoya T, Seto A, Aoyama K, Takenaka I. Development of rapid atrial fibrillation with a wide QRS complex after neostigmine in a patient with intermittent Wolff-Parkinson-White syndrome. Br J Anaesth 1999; 83: 815-818. doi: 10.1093/bja/ 83.5.815

55. Şahin SH, Öztekin İ, Kuzucuoğlu A, Aslanoğlu A. Sugammadex Use in a Patient with Wolff-Parkinson-White (WPW) Syndrome. Balkan Med J 2015; 32: 327-329. doi: 10.5152/ balkanmedj.2014.15155

56. Nakamura T, Kawahito S, Kawano H, Okada T, Kitahata H, Oshita S. Anesthetic management for repair of Ebstein's anomaly with WPW syndrome (in Japanese, with English abstract). Masui 2009; 58: 438-441 
57. Sengul T, Saracoglu A, Sener S, Bezen O. The use of sugammadex in a pregnant patient with Wolff-Parkinson-White syndrome. J Clin Anesth 2016; 33: 1-4. doi: 10.1016/j.jclinane.2015.12.023

58. Seki S, Ichimiya T, Tsuchida H, Namiki A. A case of normalization of Wolff-Parkinson-White syndrome conduction during propofol anesthesia. Anesthesiology 1999; 90: 1779-1781

59. Sato $\mathrm{Y}$, Nagata H, Inoda A, Miura H, Watanabe Y, Suzuki K. Cardioversion for paroxysmal supraventricular tachycardia during lung surgery in a patient with concealed Wolff-Parkinson-White syndrome (in Japanese, with English abstract). Masui 2014; 63: 1106-1110

60. Yamaguchi S, Nagao M, Mishio M, Okuda Y, Kitajima T. Anesthetic management using propofol and fentanyl of a patient with concealed Wolff-Parkinson-White syndrome (in Japanese, with English abstract). Masui 1998; 47: 730-733

61. Kajikawa S, Serita R. Anesthesia for thoracotomy in a patient with severe emphysema associated with Wolff-Parkinson-White syndrome (in Japanese, with English abstract). Masui 2001; 50: 555-557

62. Takayama K, Takahata O, Yamamoto Y, Nagashima K, Iwasaki H. Anesthetic management of MIDCAB in a patient with WolffParkinson-White syndrome (in Japanese, with English abstract). Masui 2000; 49: 1380-1382

63. Gupta A, Sharma J, Banerjee N, Sood R. Anesthetic management in a patient with Wolff-Parkinson-White syndrome for laparoscopic cholecystectomy Anesth Essays Res 2013; 7: 270272. doi: 10.4103/0259-1162.118988

64. Klepper I. Cardioversion in late pregnancy. The anaesthetic management of a case of Wolff-Parkinson-White syndrome. Anaesthesia 1981; 36: 611-616. doi: 10.1111/j.1365-2044. 1981.tb10325.x

65. Sadowski AR, Moyers JR. Anesthetic management of the WolffParkinson-White Syndrome. Anesthesiology 1979; 51: 553556

66. Hannington-Kiff JG. The Wolff-Parkinson-White syndrome and general anaesthesia. Br J Anaesth. 1968; 40: 791-795. doi: $10.1093 / \mathrm{bja} / 40.10 .791$

67. Campkin TV, Moore KP. The Wolff-Parkinson-White syndrome and general anaesthesia. Br J Anaesth 1969; 41: 274-276. https:/ /doi.org/10.1093/bja/41.3.274-a

68. Kadis LB, Gianelly RE. Heart and cardiovascular system. In: Katz J, Kadis LB, editors. Anesthesia and Uncommon Diseases : Pathophysiologic and Clinical Correlations. Philadelphia: Saunders; 1973: 217

69. Van der Starre PJA. Wolff-Parkinson-White syndrome during anesthesia. Anesthesiology 1978; 48: 369-372

70. Suppan P. Althesin in the Wolff-Parkinson-White syndrome. Br J Anaesth 1979; 51: 69. doi: 10.1093/bja/51.1.69

71. Rahul S, Patel R, Dewoolkar. Anaesthetic Management of W.P.W. Syndrome. The Internet Journal of Anesthesiology [Internet]. 2006 [cited 2017 Oct 29]; 11(2): [about 2 pp]. Available from: http://ispub.com/IJA/1 1/2/13272

72. Morady F, Kadish AH, Schmaltz S, Rosenheck S, Summitt J. Effects of resting vagal tone on accessory atrioventricular connections. Circulation 1990; 81: 86-90

73. Staikou C, Stamelos M, Stavroulakis E. Impact of anaesthetic drugs and adjuvants on ECG markers of torsadogenicity. Br J Anaesth 2014; 112: 217-230. doi: 10.1093/bja/aet412

74. Akbar AN, Muzi M, Lopatka CW, Ebert TJ. Neurocirculatory responses to intubation with either an endotracheal tube or laryngeal mask airway in humans. J Clin Anesth 1996; 8: 194197. doi: $10.1016 / 0952-8180(95) 00228-6$
75. Hotvedt R, Platou ES, Refsum H. Electrophysiological effects of thoracic epidural analgesia in the dog heart in situ. Cardiovasc Res 1983; 17: 259-266. doi: 10.1093/cvr/17.5.259

76. Shiroyama K, Nakagawa I, Izumi H, Kurokawa H, Kuroda M. A case of intermittent Wolff-Parkinson-White syndrome caused by high spinal anesthesia (in Japanese, with English abstract). Masui 1994; 43: 584-588

77. Lubarsky D, Kaufman B, Turndorf H. Anesthesia unmasking benign Wolff-Parkinson-White syndrome. Anesth Analg 1989; 68: $172-174$

78. Staikou C, Paraskeva A. The effects of intrathecal and systemic adjuvants on subarachnoid block. Minerva Anestesiol 2014; 80: 96-112

79. Deviseti P, Pujari VS. Spinal Anaesthesia is Safe in a Patient with Wolff-Parkinson-White Syndrome Undergoing Evacuation of Molar Pregnancy. J Clin Diagn Res 2016; 10: UD01-2. doi: 10. 7860/JCDR/2016/15751.7182

80. Brizgys RV, Shnider SM. Hyperbaric intrathecal morphine analgesia during labor in a patient with Wolff-Parkinson-White syndrome. Obstet Gynecol 1984; 64: 44S-46S

81. Namshikar V, Bharne S. Anesthesia for Wolff-Parkinson-White syndrome: A report of two cases. Saudi J Anaesth 2013; 7: 354356. doi: 10.4103/1658-354X.115342

82. Ruiz-Castro M, Sanz M, Vidal A, Infante B, Palma MA. Anesthesia for cesarean section in patients with mitral valve prolapse. Rev Esp Anestesiol Reanim 1996; 43: 291-293

83. Robinson JE, Morin VI, Douglas MJ, Wilson RD. Familial hypokalemic periodic paralysis and Wolff-Parkinson-White syndrome in pregnancy. Can J Anaesth 2000; 47: 160-164. doi: 10.1007/BF03018853

84. Misa VS, Pan PH. Evidence-based case report for analgesic and anesthetic management of a parturient with Ebstein's Anomaly and Wolff-Parkinson-White syndrome. Int J Obstet Anesth 2007; 16: 77-81. doi: 10.1016/j.ijoa.2006.05.002

85. Tachikawa M, Enomoto S, Enomoto Y, Terauchi T, Arai T, Inoue $\mathrm{H}$, et al. Anesthetic management for surgery of the ankle joint fracture in a patient with Ebstein's anomaly (in Japanese, with English abstract). Masui 2008; 57: 360-362

86. Sahu S, Karna ST, Karna A, Lata I, Kapoor D. Anaesthetic management of Wolff-Parkinson-White syndrome for hysterectomy. Indian J Anaesth 2011; 55: 378-380. doi: 10.4103/0019-5049.84866

87. Palaria U, Rasheed MA, Jain G, Sinha AK. Anesthetic management of Wolff-Parkinson-White syndrome in a pregnant patient posted for emergency caesarean section. Anesth Essays Res 2013; 7: 408-410. doi: 10.4103/0259-1162.123276

88. Kaur S, Gupta P, Aggarwal S. Anaesthetic management of WolffParkinson-White syndrome for elective caesarean section. Int J Pharm Pharm Sci 2012; 4: 755-756

89. Kabade SD, Sheikh S, Periyadka B. Anaesthetic management of a case of Wolff-Parkinson-White syndrome. Indian J Anaesth 2011; 55: 381-383. doi: 10.4103/0019-5049.84868

90. Shora A, Gurkoo S, Farooqi A, Qazi M, Nisa W. Anaesthetic management of Wolff Parkinson White syndrome for caesarean section [Internet]. The Internet Journal of Anaesthesiology 2007 [cited 2017 Oct 29]; 16(2): 4 pp. Available from https:// print.ispub.com/api/0/ispub-article/11681

91. Jacobson L, Turnquist K, Masley S. Wolff-Parkinson-White syndrome. Termination of paroxysmal supraventricular tachycardia with phenylephrine. Anaesthesia 1985; 40: 657660. doi: 10.1111/j.1365-2044.1985.tb10945.x

92. Van Zijl DH, Dyer RA, Millar RN, James MF. Supraventricular tachycardia during spinal anaesthesia for caesarean section. Int 
J Obstet Anesth 2001; 10: 202-205. doi: 10.1054/ijoa.2000. 0827

93. Okamoto T, Minami K, Shiraishi M, Ogata J, Shigematsu A. Repeated supraventricular tachycardia in an asymptomatic patient with Wolff-Parkinson-White syndrome during Cesarean delivery. Can J Anaesth 2003; 50: 752-753. doi: 10.1007/ BF03018725

94. Olgin JE, Zipes DP. Specific arrythmias: diagnosis and treatment. In: Libby P, Bonow RO, Mann DL, Zipes DP, editors. Braunwald's Heart Disease: A text book of cardiovascular medicine. $8^{\text {th }}$ ed. Philadelphia: Saunders Elsevier; 2008: 884-893

95. Bronheim D, Neustein S. Adenosine for the treatment of paroxysmal supraventricular tachycardia under general anesthesia in a patient with Wolff-Parkinson-White syndrome. J Cardiothorac Vasc Anesth 1992; 6: 218-211. doi: 10.1016/10530770(92)90204-K

96. Jones RM, Broadbent MP, Adams AP. Anaesthetic considerations in patients with paroxysmal supraventricular tachycardia. A review and report of cases. Anaesthesia 1984; 39: 307-313. doi: 10.1111/j.1365-2044.1984.tb07268.x

97. Lockey A, Balance J, Domanovits A, et al. In: Advanced Life Support, ERC Guidelines, Course Manual. $6^{\text {th }}$ ed. Edegem, Belgium: European Resuscitation Council vzw.; 2010: 83-84, 112-115

98. Wheeler DW, Sayeed RA, Ritchie AJ. Unsuspected WolffParkinson-White syndrome causing arrhythmias after cardiac surgery. J Cardiothorac Vasc Anesth 2002; 16: 354-356. doi: $10.1053 /$ jcan.2002.124148

99. Nishikawa K, Mizoguchi M, Yukioka H, Asada A, Fujimori M. Concealed Wolff-Parkinson-White syndrome detected during spinal anaesthesia. Anaesthesia 1993; 48: 1061-1064. doi: 10.1111/j.1365-2044.1993.tb07527.x

100. Chhabra A, Trikha A, Sharma N. Unmasking of benign WolffParkinson-White pattern under general anaesthesia. Indian J Anaesth 2003; 47: 208-211

101. Esenther B, Ko R. Smartphones in the Operating Room: Distraction or Diagnostic Aid? A Case of Newly Diagnosed WolffParkinson White in a Pediatric Patient Having Bronchoscopy Under General Anesthesia. A A Case Rep 2015; 5: 40-42. doi: 10.1213/XAA.0000000000000176

102. Fitzsimmons PJ, McWhirter PD, Peterson DW, Kruyer WB. The natural history of Wolff-Parkinson-White syndrome in 228 military aviators: a long-term follow-up of 22 years. Am Heart J 2001; 142: 530-536. doi: 10.1067/mhj.2001.117779

103. Braun U, Weyland A, Bartmus D, Ruschewski W, Rath W. Anesthesiologic aspects of pregnancy and delivery in a patient following a modified Fontan procedure. Anaesthesist 1996; 45: 545-549

104. Mahaim I, Benatt A. Nouvelles recherches sur les connexions supérieures de la branche gauche du faisceau de His-Tawara avec cloison interventriculaire. Cardiologia 1938; 1: 61-120. doi: $10.1159 / 000164567$

105. Sternick EB, Timmermans C, Rodriguez LM, Wellens HJ. Mahaim fiber: an atriofascicular or a long atrioventricular pathway?
Heart Rhythm 2004; 1: 724-727. doi: 10.1016/ j.hrthm.2004.07.015

106. Sternick EB, Wellens HJJ. Chapter 3: Atriofascicular pathways and decrementally conducting long atrioventricular pathways. In: Sternick EB, Wellens HJJ, editors. Variants of Ventricular Preexcitation: Recognition and Treatment. Malden, Massachusetts, USA: Blackwell Publishing, 2006: 15-58. doi: 10.1002/9780470994993.ch3

107. Aliot E, de Chillou C, Revault d'Allones G, Mabo P, Sadoul N. Mahaim tachycardias. Eur Heart J 1998; 19 Suppl E: E25-31, E52-53

108. Zweifler IA, Rosenberg AD, Chinitz L. An unusual preinduction arrhythmia resulting from the presence of a Mahaim fiber. J Clin Anesth 2011; 23: 489-491. doi: 10.1016/j.jclinane. 2010.09.010

109. Lown B, Ganong WF, Levine SA. The syndrome of short PR interval, normal QRS complex and paroxysmal rapid heart action. Circulation 1952; 5: 693-706. doi: 10.1161/01. CIR.5.5.693

110. Sharma MK, Misra S. Anaesthetic management of a patient with Lown Ganong Levine syndrome - a case report. Med J Armed Forces India 2011; 67: 285-287. doi: 10.1016/S03771237(11)60064-6

111. Ometto R, Thiene G, Corrado D, Vincenzi M, Rossi L. Enhanced A-V nodal conduction (Lown-Ganong-Levine syndrome) by congenitally hypoplastic A-V node. Eur Heart J 1992; 13: 15791584. doi: 10.1093/oxfordjournals.eurheartj.a060104

112. James TN. Morphology of the human atrioventricular node, with remarks pertinent to its electrophysiology. Am Heart J 1961; 62: 756-771. doi: 10.1016/0002-8703(61)90664-0

113. Brechenmacher C, Laham J, Iris L, Gerbaux A, Lenègre J. Etude histologique des voies anormales de conduction dans un syndrome de Wolff-Parkinson-White et dans un syndrome de LownGanong-Levine. Arch Mal Coeur Vaiss 1974; 67: 507-519

114. Ward DE, Camm J. Mechanisms of junctional tachycardias in the Lown-Ganong-Levine syndrome. Am Heart J 1983; 105: 169-175. doi: 10.1016/0002-8703(83)90304-6

115. Wiener I. Syndromes of Lown-Ganong-Levine and enhanced atrioventricular nodal conduction. Am J Cardiol 1983; 52: 637639. doi: 10.1016/0002-9149(83)90042-5

116. Jones RM, Broadbent MP, Adams AP. Anaesthetic considerations in patients with paroxysmal supraventricular tachycardia. A review and report of cases. Anaesthesia 1984; 39: 307-313. doi: 10.1111/j.1365-2044.1984.tb07268.x

117. Eichholz A, Whiting RB, Artal R. Lown-Ganong-Levine syndrome in pregnancy. Obstet Gynecol 2003; 102: 1393-1395. doi: 10.1016/S0029-7844(03)00708-7

118. Kannan S, Sherwood N. Termination of supraventricular tachycardia by propofol. Br J Anaesth 2002; 88: 874-875. doi: $10.1093 / \mathrm{bja} / 88.6 .874$

119. Mackenzie R. Short PR interval. J Insur Med 2005; 37: 145152 